\title{
Fuel characteristics, loads and consumption in Scots pine forests of central Siberia
}

\author{
Galina A. Ivanova ${ }^{1} \cdot$ Elena A. Kukavskaya ${ }^{1}$. \\ Valery A. Ivanov ${ }^{2}$ Susan G. Conard ${ }^{3,4}$. \\ Douglas J. McRae ${ }^{5}$
}

Received: 3 April 2019 / Accepted: 13 May 2019 / Published online: 24 September 2019

(C) The Author(s) 2019

\begin{abstract}
Forest fuel investigations in central and southern Siberian taiga of Scots pine forest stands dominated by lichen and feather moss ground vegetation cover revealed that total aboveground biomass varied from 13.1 to $21.0 \mathrm{~kg} /$ $\mathrm{m}^{2}$. Stand biomass was higher in plots in the southern taiga, while ground fuel loads were higher in the central taiga. We developed equations for fuel biomass (both aerial and ground) that could be applicable to similar pine forest sites of Central Siberia. Fuel loading variability found among plots is related to the impact and recovery time since the last wildfire and the mosaic distribution of living vegetation.
\end{abstract}

Project funding: This research was funded by National Aeronautics and Space Administration (NASA) Land Cover Land Use Change (LCLUC) Science Program; the Russian Fund of Fundamental Investigation; the United States Department of Agriculture (USDA), Forest Service; Natural Resources Canada, Canadian Forest Service; and the Russian Academy of Sciences, Siberian Branch.

The online version is available at http://www.springerlink.com

Corresponding editor: Yu Lei.

Galina A. Ivanova

GAIvanova@ksc.krasn.ru

1 V.N. Sukachev Institute of Forest SB RAS - Separate Subdivision of the Federal Research Center "Krasnoyarsk Science Center of the Siberian Branch of the Russian Academy of Sciences", Krasnoyarsk, Russia 660036

2 M.F. Reshetnev Siberian State University of Science and Technology, Krasnoyarsk, Russia 660049

3 Emeritus Scientist, Rocky Mountain Research Station, U.S. Forest Service, Missoula, MT 59807, USA

4 George Mason University, Fairfax, VA, USA

5 Canadian Forest Service, Natural Resources Canada, 1219 Queen Street East, Sault Ste. Marie, ON P6A 2E5, Canada
Fuel consumption due to surface fires of low to high-intensities ranged from 0.95 to $3.08 \mathrm{~kg} / \mathrm{m}^{2}$, that is, $18-74 \%$ from prefire values. The total amount of fuels available to burn in case of fire was up to $4.5-6.5 \mathrm{~kg} / \mathrm{m}^{2}$. Moisture content of fuels (litter, lichen, feather moss) was related to weather conditions characterized by the Russian Fire Danger Index (PV-1) and FWI code of the Canadian Forest Fire Weather Index System. The data obtained provide a strong foundation for understanding and modeling fire behavior, emissions, and fire effects on ecosystem processes and carbon stocks and could be used to improve existing global and regional models that incorporate biomass and fuel characteristics.

Keywords Pinus sylvestris $\cdot$ Tree biomass $\cdot$ Surface and ground fuel loads $\cdot$ Fuel moisture $\cdot$ Fuel consumption

\section{Introduction}

Boreal forest ecosystems contain large stores of carbon and occur in northern regions where climate is warming most rapidly and fires are becoming more frequent and more severe (Groisman et al. 2017). Because Russia contains some two-thirds of the global boreal forest, accurate data on fuel characteristics and impacts of fire in these systems are particularly important for improving our understanding of fuel consumption, emissions, and effects of fire on regional and global carbon stocks. Even within Russia, forests vary widely in biomass and fuel characteristics and in fire regimes-differences that are often not captured in global models or appreciated by forest managers or decisionmakers.

Among about 1200 million ha of boreal forests in Russia, 115.2 million ha are dominated by Scots pine (Pinus sylvestris). About $18 \%$ of all forest fires in Russia occur in Scots pine stands (Bartalev et al. 2015). About 65\% of the 
Scots pine forests are in Siberia, east of the Ural Mountains (Forest Fund of Russia 1999). The ground covers most frequently burned in these stands are grass, lichen and moss (Korovin 1996). Although a number of studies have characterized specific fuel layers in these types of forests, few have described the loading of all components, compared fuels across or within sites, or used fuel data in conjunction with data on fire behavior or fuel consumption from subsequent fires. The data on fuel consumption in Siberia are very limited (FIRESCAN 1996; McRae et al. 2006; Ivanova et al. 2011; Kukavskaya et al. 2013b).

The biomass in forest ecosystems is distributed vertically and includes one or more forest canopy layers (e.g., tree foliage, living and dead tree branches), surface layers (e.g., grasses, shrubs and small trees, and dead down woody pieces), and ground layers (e.g., lichen, moss, humus, peat, and roots) (Byram 1959). Knowledge of the forest fuel complex is important for predicting forest fire danger, potential forest fire behavior, and the effects of fire on carbon stocks and the atmosphere that are determined by fuel consumption. Fuel characteristics that affect fire behavior include fuel load, continuity, structure, moisture content, and chemical composition (Davis 1959; Kurbatsky 1962; Albini 1976; Anderson 1982; Ottmar et al. 2007). A number of systems have been developed for classifying fuels and determining their influence on fire characteristics or effects. These systems often combine fuel information with weather-based indices of fire danger. In Russia, the PV-1 Index is used to estimate fire danger (Vonsky et al. 1975). PV-1 is calculated from a combination of current and antecedent weather (temperature, humidity deficit, and precipitation), but does not include a fuel component. The Canadian Forest Fire Weather Index (FWI) System (Canadian Forestry Service 1987) is a weather-based system that divides the forest floor (litter, moss, lichen, and duff) fuels into three layers (Van Wagner 1987) to account for different drying rates that are related to increasing compaction and decomposition with depth. This system was developed for Canada which has extensive boreal forests, but it has been applied successfully in many other regions and vegetation types (Venäläinen et al. 2014.). The National Fire-Danger Rating System (NFDRS) developed in the United States (Burgan and Rothermel 1984) divides fuels into two categories: dead and live. The dead fuel category consists of four diameter classes categorized by drying time (timelag), and live fuels include two classes (live herbaceous and live woody). Kurbatsky $(1962,1970)$ divided forest fuels into seven categories based on their position in the ecosystem: Group I, mosses, lichens, and small-sized plant residues; Group II, forest floor, humus, and peat horizons; Group III, grasses and small shrubs; Group IV, large dead woody elements (fallen branches and trees, snags, stumps, logging slash); Group V, tree regeneration and tall shrubs; Group VI, living tree foliage and branches up to $7 \mathrm{~mm}$ in diameter; and Group VII, living tree stems and branches $>7 \mathrm{~mm}$ in diameter. This system is not linked directly to fire behavior or fuel consumption models. Kurbatsky (1970) also assigned forest fuels to one of three categories based on their contribution to fire behavior: fire carriers, fire supporters, or fire retarders. Fire carriers include surface fuels that can independently carry a surface fire, such as mosses, lichens, litter, cured grass, and logging slash. This category also includes organic layers such as peat and rootstocks of perennial grasses (sod), which can carry smoldering ground fires. Fire supporters are fuels that can facilitate fire spread through carrier fuels. This category includes dead and down woody branches and stems, some grasses and small shrubs (e.g., Ledum sp., Calluna sp., Vaccinium vitis-idaea), young conifer regeneration, standing snags, tall shrubs, and highly resinous living tree stems. Fire retarders include live plants in the grass/small shrub layer that have high moisture content at the time of fire (e.g., bearberry [Arctostaphylos uvaursi]) as well as green foliage of deciduous woody species.

Fires never consume the entire biomass of a living forest, because much of it is too moist to burn, or too discontinuous to sustain a fire. The mass of surface and ground fuels combusted is determined by their biomass loading, structure, and moisture content (Kurbatsky and Ivanova 1987). Some researchers in Russia have classified all dead plant materials (sometimes including living mosses) above the mineral soil as forest floor (Rodin and Bazelevich 1965; Pozdnyakov et al. 1969; Vedrova et al. 2000). From a fire viewpoint, it is very important to distinguish between the litter layer and the decomposing forest floor ( $\mathrm{F}$ and $\mathrm{H}$ layers) below, since the litter layer is the most important fuel component in actively carrying fire along with lichens, mosses, and dried grasses, leaves, and needles. These are the primary fuels consumed under the surface fire regime that accounts for about $80 \%$ of the annual area burned in Russia (Korovin 1996). Litter can consist of dead and down woody pieces, which are deposited on the surface of the moss and lichen layer, as well as any cured herbs and dead foliage that have fallen onto the layer. Often dead herbs and fallen conifer needles get caught and hang-up on whortleberry ( $V$. vitis-idaea) shrubs found in Scots pine (P. sylvestris)-mixed herbs- $V$. vitis-idaea forest stands. Litter can sometimes be directly deposited on top of the forest floor soil surface in forest stands with no ground cover (i.e., sites devoid of any lichen or moss cover). The rate of litter and forest floor accumulation is strongly dependent on forest type, understory composition and cover, stocking, and age class (Melekhov 1957). Fuel load and fuel properties are dynamic and can vary throughout the year. Herb biomass increases in the spring, while the moisture content gradually decreases during the growing season. Cured and fallen vegetation from previous years is compressed and incorporated into the forest floor and its fuel load then decreases as a result of decomposition. These 
constant changes determine the natural fuel dynamics in a forest stand, especially those with large amounts of herbaceous and shrub vegetation types that create a loosely packed fuel layer in spring (Kurbatsky and Ivanova 1987). Increases in the biomass of living herbs and shrub foliage during the growing season can alter the microclimate and the overall moisture of the fuel bed sufficiently to inhibit ecosystem flammability and fire spread, especially on herb- and shrubrich sites (Deeming et al. 1972; Baranov 1976).

Fuel layers in Siberian taiga forests include fine-textured hygroscopic materials (litter, mosses, lichens), whose moisture content can range from low (10-30\%) to highly saturated (up 300\% and more) and may change relatively rapidly in response to rain or temperature and relative humidity. On the other hand, living shrubs and herbaceous vegetation respond more slowly to the environment and may often have moisture contents of $120-400 \%$ when the hygroscopic fractions of litter, mosses and lichen are quite dry. Forest fuel layer development and structure are impacted by a number of factors, such as vegetation type, precipitation pattern, and fire frequency. Needle-fall at the end of the growing season leads to a relatively even distribution of fallen needles across the litter surface of central Siberian Scots pine stands by mid-August (Elagin 1976). The rate of decomposition of this litter is significantly reduced by the high resin content of newly fallen needles and twigs (Atkin 1984). This results in the accumulation of duff that is characterized by high water-retention capacity (Bannikova 1967). Amosov (1964) reported that loadings of fine surface fuels in pine forests with lichen and grass ground cover that are lower than about $0.2 \mathrm{~kg} / \mathrm{m}^{2}$ are insufficient to allow fire to spread well. However, Sofronov (1988) found that an evenly distributed, cured sedge layer with a fuel load of only $0.05 \mathrm{~kg} / \mathrm{m}^{2}$ could carry fire if quite dry. According to Valendik and Gevel (1975) fire spreads through dry grasses with moisture content less than $26 \%$. The dynamics, structure, and composition of surface and ground fuels are complex and site-specific. Fuel loading and structure are determined by vegetation type, moisture and temperature conditions, soil type, permafrost presence, and time since the last fire (Melekhov 1947, 1957; Kurbatsky 1962; Morgan et al. 2001; Ivanova et al. 2007). Site characteristics, terrain, and weather conditions at the time of the fire, including wind speed, are also important factors in limiting or promoting fire spread (Valendik 1990).

Our study focused on quantifying the forest fuel structure, characteristics and consumption in typical Scots pine-lichen (Cladonia sp.)-feather moss [Pleurozium schreberi (Brid.) Mitt.] forests of the Siberian central and southern taiga. These data improve the knowledge of the biomass and fuel characteristics that are necessary for the effective fire management and accurate modeling in these extensive and frequently burned Scots pine forest types. This work is part of a larger interdisciplinary study, the Fire Effects in the Boreal
Eurasia Region (FIRE BEAR) Project that was developed to quantify the impacts of fire on carbon cycle, emissions, and forest health and sustainability in Central Siberia. The data discussed here provided a basis for studying fire behavior, and fire impact on carbon stocks and various ecosystem components. In addition, fuel consumption data are essential for improving fire emission estimates in Siberia.

\section{Materials and methods}

\section{Study sites}

We investigated forest fuel loads on three sites in Scots pine stands of central Siberia (Fig. 1). For convenience, we identify the study sites by the names of the nearest villages. The Yartsevo study site is in the central taiga subzone, west of the Yenisey River on the Sym plain of the Western Siberian Lowland $\left(60^{\circ} 38^{\prime} \mathrm{N}, 89^{\circ} 41^{\prime} \mathrm{E}\right) 55 \mathrm{~km}$ northwest of the village of Yartsevo and is an area of intermixed sand islands, bogs, and lakes typical of vast areas of western Siberia. The climate is characterized by cool and humid conditions, with an average annual air temperature ranging from -3.2 to $-5.7^{\circ} \mathrm{C}$ and total precipitation of $400-500 \mathrm{~mm}$. Precipitation occurs throughout the year, with up to $60 \%$ of it falling in the summer (Zhukov et al. 1969). There is no underlying permafrost. The dry Scots pine stands with lichen and feather moss-dominated ground vegetation are characterized by sandy podzolic soils. The site quality classes are IV and V (Anuchin 1982), which indicates poor growing conditions. Pine regeneration, consisting of up to $0.5-\mathrm{m}$ high Scots pine, was uniformly distributed across the site. Taller regeneration (2.0-3.5 m high) occurred in small pockets across some of the plots, where gaps in the canopy had resulted from past fires. Sparse tall shrubs included wild rose (Rosa acicularis Lindl.) and willow (Salix caprea L.).

The Govorkovo and Khrebtovo sites are in the southern taiga subzone of the Lower Angara region. Compared to the central taiga, stands of the southern taiga are more productive (tree volume can be as much as 50-60\% higher), and living ground cover is more diverse (Zhukov et al. 1969). The Govorkovo site $\left(58^{\circ} 35^{\prime} \mathrm{N}, 98^{\circ} 55^{\prime} \mathrm{E}\right)$ is south of the Angara River and $60 \mathrm{~km}$ southeast of the village of Govorkovo. The Khrebtovo site $\left(58^{\circ} 42^{\prime} \mathrm{N}, 98^{\circ} 25^{\prime} \mathrm{E}\right)$ is north of the Angara River and $20 \mathrm{~km}$ north of the village of Khrebtovo (Fig. 1). The climate of this region is strongly continental, with an average annual air temperature of $-2.0^{\circ}$ to $-2.4{ }^{\circ} \mathrm{C}$ and annual precipitation of 320-380 mm (Central Siberia 1964). The soils are illuvial-ferruginous sandy podzols, which are more fertile than soils at the Yartsevo site. The site quality class is III (Anuchin 1982). Uniformly distributed regenerated pines consisted of up to $0.5-\mathrm{m}$ high Scots pine, while taller trees had regenerated only in Plot 2 in Govorkovo. The 


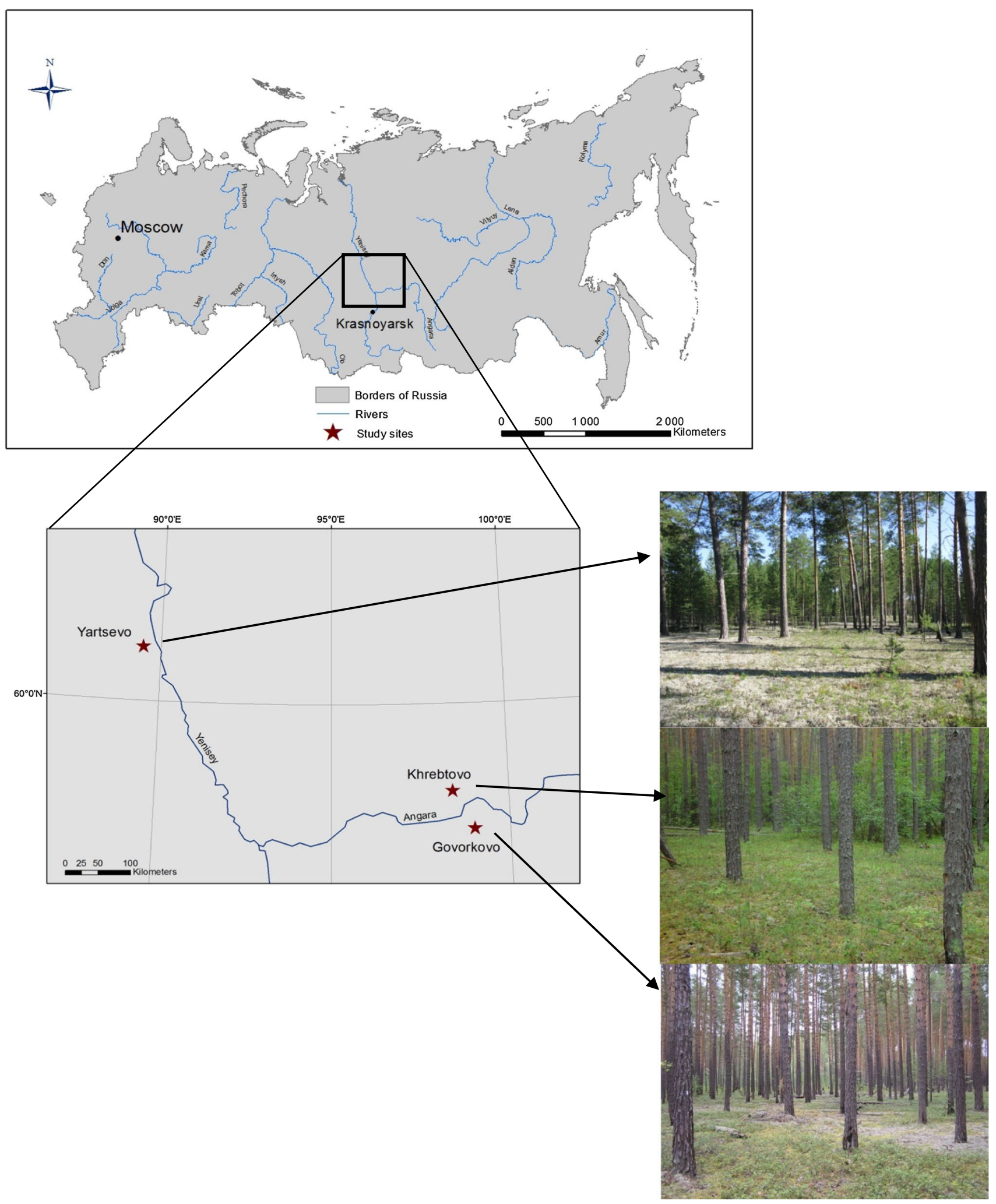

Fig. 1 Map of location of study sites and view of the Scots pine forests in Russia 
Scots pine-lichen-feather moss stand on the Govorkovo site is on a flat bench of a gradual slope. It is a xeric forest type, similar to the Yartsevo site. The tall shrub layer contains willow (S. caprea L.), dog rose (R. acicularis Lindl.), and mountain ash (Sorbus sibirica Hedl.). The Khrebtovo site is on a gentle slope in more mesic conditions than at the other two sites, as indicated by the herb-feather moss ground cover. This site is level with minimal microrelief and with nanorelief formed by down dead wood of varying ages. The tall shrub layer averages $3.5 \mathrm{~m}$ high and contains mainly alder (Alnus fruticosa Rupr.), with scattered individuals of willow, dog rose, honeysuckle (Lonicera tatarica L.), and spiraea (Spiraea media Franz Schmidt).

Summer drought periods, which lead to periods of high fire danger, are common on all study sites (Valendik 1990; Valendik and Ivanova 1996). The pure pine forest stands at

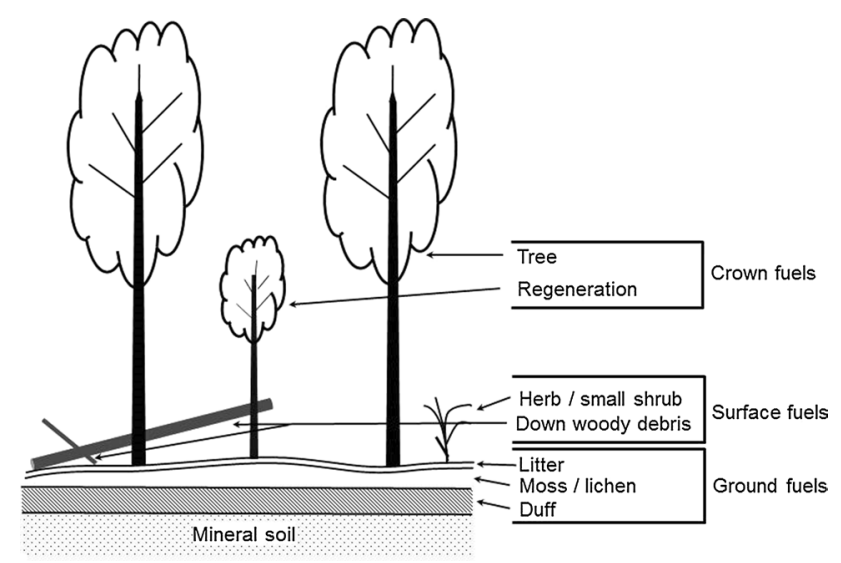

Fig. 2 Schematic representation of fuel categories (crown, surface, and ground) used and fuel types within each category
Yartsevo were of fire origin and included several age groups: $450,275,185,130$, and 45 years of age. The average landscape wildfire interval was approximately 50 years (Ivanova 2005). The last wildfire that occurred on the experimental site was in 1956. The Scots pine stand at Govorkovo last burned in 1946 and included the following age groups: 200, 130, 80, and 50 years. The landscape wildfire interval was 30-70 years. The last fire on the Khrebtovo site was in 1948. The forest stand included age groups: $205,170,90$, and 55 years. The average landscape wildfire interval was approximately 46 years.

We analyzed fuel loads above the mineral layer, including crown, surface, and ground fuels (Fig. 2). We obtained fuel data from 13 plots measuring that were established at the experimental sites in preparation for a series of planned prescribed fires: nine plots in Yartsevo, two plots in Govorkovo, and two plots in the Khrebtovo study area. These plots represented a range of forest stand conditions within this Scots pine forest type. Plots were approximately $200 \times 200 \mathrm{~m}$ (4 ha). A $25 \times 25 \mathrm{~m}$ sampling grid was laid out on each plot using numbered metal pins (normally 49 pins in a $7 \times 7$ grid) (Fig. 3).

We estimated mean density of trees $\geq 10 \mathrm{~cm}$ DBH by a point-centered quarter (PCQ) method (Morisita 1957). The centers of PCQ plots were offset by $1 \mathrm{~m}$ from the points on the sampling grid for each plot (Fig. 3). We measured height, diameter, and distance from the center point for four trees at every other sample point, for a total of 25 sample grid points (100 trees) per plot. Plot characteristics for both live and dead trees are summarized in Table 1 . We calculated stand diameter at breast height (DBH) as a quadratic mean of the average basal area. Mean height is reported as the mean height of trees at the quadratic mean diameter, and

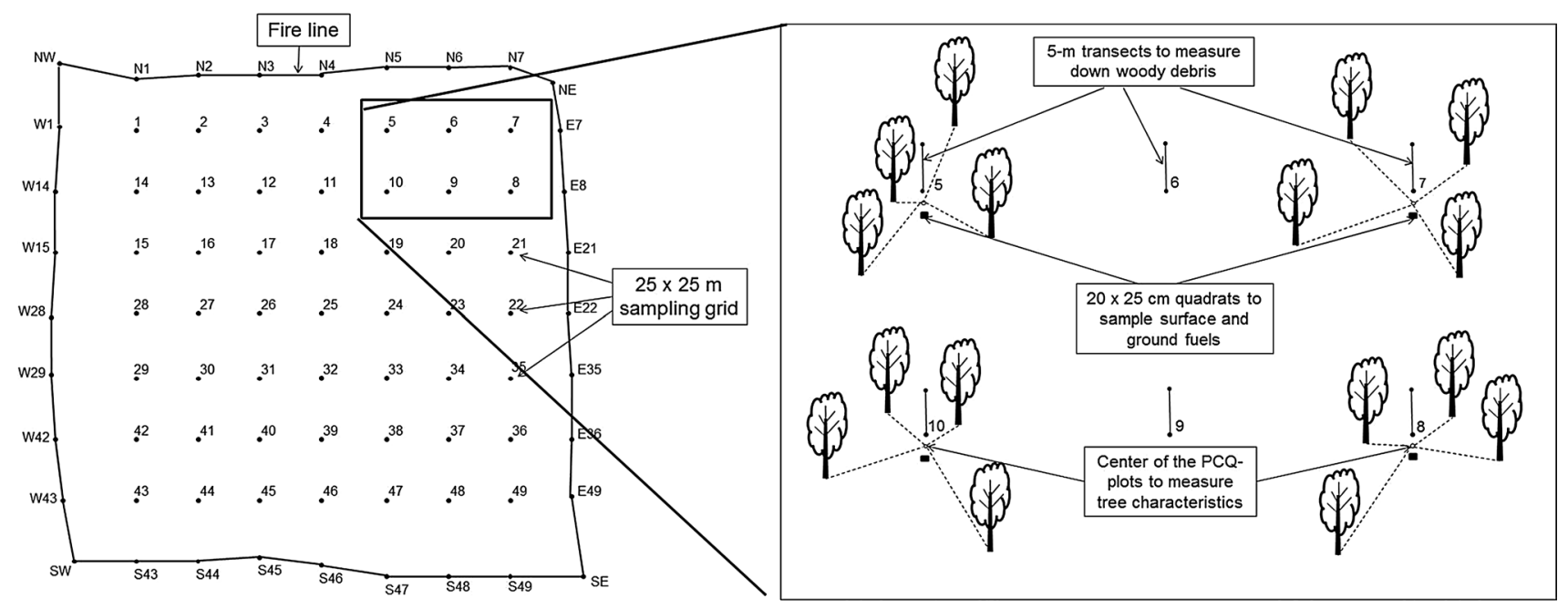

Fig. 3 Diagram of basic sampling layout for each plot that illustrates the location of various types of fuel sampling relative to the grid points. Each plot was bordered by a fire line cleared to mineral soil. Point-centered quarter (PCQ) plots were established at alternate grid points 
Table 1 Stand structure characteristics of Scots pine forests on individual 4-ha study plots at study sites in the central and southern taiga in Russia

\begin{tabular}{|c|c|c|c|c|c|c|}
\hline \multirow[t]{2}{*}{ Plot } & \multirow[t]{2}{*}{ Average DBH $(\mathrm{cm})$} & \multirow[t]{2}{*}{ Average height (m) } & \multirow{2}{*}{$\begin{array}{l}\text { Height to live } \\
\text { crown }(\mathrm{m})\end{array}$} & \multirow[t]{2}{*}{ Density (stems/ha) } & \multicolumn{2}{|c|}{ Stand basal area } \\
\hline & & & & & Total $\left(\mathrm{m}^{2} / \mathrm{ha}\right)$ & Live trees $(\%)$ \\
\hline \multicolumn{7}{|c|}{ Central taiga (Yartsevo site) } \\
\hline 2 & 32.4 & 19.8 & 12.0 & 191 & 15.7 & 100 \\
\hline 3 & 32.4 & 19.0 & 10.0 & 204 & 16.8 & 88 \\
\hline 4 & 32.1 & 19.8 & 12.5 & 331 & 26.9 & 85 \\
\hline 6 & 31.5 & 19.7 & 12.5 & 435 & 33.9 & 92 \\
\hline 13 & 30.8 & 20.8 & 10.0 & 297 & 22.1 & 100 \\
\hline 14 & 36.7 & 20.6 & 10.6 & 198 & 20.9 & 100 \\
\hline 19 & 27.3 & 17.8 & 10.9 & 321 & 18.8 & 90 \\
\hline 20 & 26.2 & 17.5 & 11.1 & 598 & 32.2 & 99 \\
\hline 21 & 28.7 & 18.1 & 10.6 & 427 & 27.5 & 100 \\
\hline Average (SE) & $30.9(1.1)$ & $19.2(0.4)$ & $11.1(0.3)$ & $333.6(45.0)$ & $23.9(2.2)$ & $94.9(2.0)$ \\
\hline \multicolumn{7}{|c|}{ Southern taiga (Govorkovo and Khrebtovo sites) } \\
\hline 1 & 24.8 & 21.0 & 13.3 & 831 & 40.3 & 97 \\
\hline 2 & 24.2 & 20.8 & 11.3 & 344 & 15.8 & 94 \\
\hline 3 & 24.1 & 20.4 & 12.2 & 1118 & 51.1 & 96 \\
\hline 5 & 19.3 & 18.6 & 13.2 & 1422 & 41.5 & 96 \\
\hline Average (SE) & $23.1(1.3)$ & $20.3(0.6)$ & $12.5(0.5)$ & $928.8(229)$ & $37.5(7.5)$ & $95.8(0.6)$ \\
\hline
\end{tabular}

basal area (BA) was based on cumulative BA of individual trees (Vagin et al. 1978).

\section{Tree fuel sampling}

We estimated aboveground fuels for Scots pine by developing biomass regressions from harvested trees across a range of size classes (e.g., Walker and Stocks 1975; Stocks 1980). Sample trees covered the range of DBH classes present at the site. Sixteen trees, with DBH from 4 to $44 \mathrm{~cm}$, were felled and destructively sampled. The stump portion of each tree was cut off at the ground surface and included in the total tree stem biomass. Any tree pieces broken off during the felling operation were retrieved, and all tree components were placed on tarps to ensure that no materials were lost. For each tree, we measured DBH, diameter at stump height, total tree height, stump height, height to living crown, height to the lowest live and dead branch, and crown width. Stem diameter was measured at 2-m intervals starting at the point the tree was cut. The 2-m increments of tree bole were weighed in the field. Tree age was determined by counting growth rings on each stump. All branches were removed from the main stem of each tree and separated into standard fuel diameter classes (0.0-0.49, 0.5-0.99, 1.0-2.99, 3.0-4.99, and 5.0-6.99-cm size classes) using a go-no-go gauge (McRae et al. 1979). All branch diameter classes for dead and living fractions and needles on small twigs, were weighed separately. After weighing, three subsamples were taken of each branch diameter class (for both live and dead branches) and of each bole section for dry mass determination. Cones found on branches were collected, weighed, and subsampled to weigh dry mass. All subsamples were returned to the laboratory and dried at $100{ }^{\circ} \mathrm{C}$ until they reached constant mass. Crown needle biomass was calculated using conversion coefficients. For each tree, 15-20 living twigs with needles were partitioned into twig and needle components to determine the ratio of needle biomass (dry mass) to that of the live $0.0-0.49 \mathrm{~cm}$ twig. The average ratio for each sample tree was used to estimate overall dry mass of needles and small twigs for that tree.

\section{Surface and ground fuel sampling}

The line intersect method of Van Wagner (1968), as adapted by McRae et al. (1979), was modified slightly for measuring the dead and down woody fuels (DDWF) before and immediately after each fire. Five-meter transects were placed at all 49 grid sample points on each plot (Fig. 3). Due to the random natural fall of material, the transect orientations were kept similar to simplify the sampling set-up and relocation of transect for later postfire sampling. The number of fuel pieces $<7.0 \mathrm{~cm}$ in diameter were tallied into standard 0.0-0.49, 0.5-0.99, 1.0-2.99, 3.0-4.99, and 5.0-6.99 cm diameter fuel size classes along the entire length of each 5-m transect using a metal "go-no-go" gauge that had templates for each size class. The jack pine (Pinus banksiana) multiplication factor of McRae et al. (1979) was used to obtain the fuel load $\left(\mathrm{kg} / \mathrm{m}^{2}\right)$, as jack pine and Scots pine have similar small branch diameters. The diameters of 
woody pieces $\geq 7.0 \mathrm{~cm}$ in diameter were determined using calipers, and decomposition level (solid vs. rotten) was recorded. Surface vegetation and ground fuel loadings were sampled using methods of Walker and Stocks (1975) and Alexander et al. (1991). Twenty-five $20 \times 25$-cm fuel quadrats were laid out per plot, one at every other grid point (Fig. 3). The sample location was offset $2 \mathrm{~m}$ away from each grid point so as not to interfere with other sampling. The aboveground components of small vegetation (herbs and small shrubs, e.g., Vaccinium spp.) within the sampling frame were collected before forest floor samples. Litter (needles, cones, and bark pieces) was collected as a separate fraction from on top of any living ground cover. The projected covers of moss and lichen were determined by ocular estimation to the nearest $5 \%$. The outer edge of the sample quadrat was then cut using a knife and duff was stripped off in 2-cm layers until the mineral soil was reached. Forest floor depth (to mineral soil) for each sample quadrat was determined by averaging four measurements per quadrat (one in each corner). Because these methods do not estimate fuel loads for live mosses and lichens separately from the duff layer, we collected an additional 10 fuel samples near each experimental plot for which lichens and mosses were separated from the duff. The ratio of lichens + mosses to duff obtained was used to determine the contribution of different fuel types to the total loads on our experimental plots. To determine fuel consumption, we placed two depth-of-burn pins $1 \mathrm{~m}$ on either side of the end DDWF sampling pin.

Samples for surface and ground fuel moisture content were taken immediately before experimental burns, on areas adjacent to each experimental plot and with similar vegetation composition and structure. In addition, in 2003 we collected daily samples for fuel moisture for a month (July), and during other years, we collected up to 150 samples of different fuels annually adjacent to our experimental plots in similar vegetation. Herbs and small shrubs, mosses and lichens (collected from both sunny and shaded ground locations), and litter were sampled. Six samples per fuel category were taken and averaged to obtain data on moisture content. The samples were oven-dried in the laboratory, and moisture content of each sample was calculated as percentage of dry mass. Weather characteristics (temperature, relative humidity, pressure, wind speed and direction, and precipitation) were measured at an onsite weather station that was established near the experimental plots and maintained during June and July. For the early part of the fire season, we used data from the nearby weather stations.

The moisture content of different surface and ground fuel types (litter, lichen, and moss) was analyzed as a function of weather conditions, as characterized by the Russian Fire Danger Index (PV-1). PV-1 was calculated as:

$\mathrm{PV}-1=\sum t(t-\tau) \kappa$ where $t$ is temperature $\left({ }^{\circ} \mathrm{C}\right)$ at 13:00 $\mathrm{h} \mathrm{DST}, \tau$ is dew point temperature $\left({ }^{\circ} \mathrm{C}\right)$, and $\kappa$ is the precipitation coefficient (Vonsky et al. 1975).

\section{Burning procedures}

Experimental plots were burned over four consecutive years in June and July, which corresponds to the main fire season for this region. Yartsevo sites were burned in 2000-2002 (Plots 13 and 14 in 2000; Plots 2, 3, 6, 19 in 2001; and Plots 4, 20, 21 in 2002); Govorkovo and Khrebtovo sites were burned in 2002-2003 (Plots 1 and 2 in 2002; Plots 3 and 5 in 2003). All plots were burned using line ignition along the windward side to mimic equilibrium fire behavior conditions. Fires were primarily surface fires, but they ranged widely in fire behavior and in fire severity (McRae et al. 2006; Ivanova et al. 2011).

Byram's (1959) equation was used to calculate fireline intensity as a product of rate of spread, dry mass of consumed fuel, and heat of combustion of consumed fuel (McRae et al. 2006 updated). Fires were classified into lowintensity fires with fireline intensity being up to $2000 \mathrm{~kW} / \mathrm{m}$, moderate-intensity (2001-4000 kW/m), and high-intensity fires (more than $4001 \mathrm{~kW} / \mathrm{m}$ ).

\section{Results and discussion}

\section{Tree biomass and crown fuels}

Both individual fuel components of the trees and total tree biomasses showed close relationships with tree DBH, height, and age (Table 2), with the highest correlation coefficients obtained for tree DBH. We explored a number of independent variables, and concluded that regressions based on the logarithm of DBH provided the best models for representing biomass components across the range of our sampled trees. Our goal was to find a monotonic functional form that fit the data as well as possible, while minimizing both proportional error and the number of parameters in the equation. The general form of the resulting series of equations for estimating total Scots pine tree biomass and biomass of individual components is:

$\log _{10} B=b_{0}+b_{1} \times \log _{10} \mathrm{DBH}+b_{2} \times\left(\log _{10} \mathrm{DBH}\right)^{2}$,

where $B$ represents biomass $(\mathrm{kg}) ; b_{0}, b_{1}$ and $b_{2}$ are coefficients that were estimated for the logarithms of the various biomass components; and DBH is the diameter at breast height $(\mathrm{cm})$. The fitted values of the parameters $\left(b_{0}, b_{1}\right.$, $b_{2}$ ) for the logarithms of biomass components are listed in Table 3. 
Table 2 Correlations $(R)$ between Scots pine component and tree $\mathrm{DBH}$, height and age

\begin{tabular}{llll}
\hline Tree component & DBH $(\mathrm{cm})$ & Tree height $(\mathrm{m})$ & Tree age (year) \\
\hline Living branches by size class & & & \\
$0.0-0.49$ & $0.86^{*}$ & $0.75^{* *}$ & $0.85^{*}$ \\
$0.5-0.99$ & $0.81^{* *}$ & $0.77^{* *}$ & $0.75^{* *}$ \\
$1.0-2.99$ & $0.93^{*}$ & $0.85^{*}$ & $0.93^{*}$ \\
$3.0-4.99$ & $0.52^{* * * *}$ & $0.47^{\#}$ & $0.52^{* * * *}$ \\
$5.0-6.99$ & $0.74^{* *}$ & $0.49^{\#}$ & $0.49^{\#}$ \\
Total & $0.92^{*}$ & $0.77^{* *}$ & $0.90^{*}$ \\
Dead branches by size class & & & \\
$0.0-0.49$ & $0.63^{* * *}$ & $0.75^{* *}$ & $0.53^{* * * *}$ \\
$0.5-0.99$ & $0.68^{* * *}$ & $0.79^{* *}$ & $0.58^{* * * *}$ \\
$1.0-2.99$ & $0.90^{*}$ & $0.75^{* *}$ & $0.93^{*}$ \\
3.0-4.99 & $0.85^{*}$ & $0.44^{\#}$ & $0.99^{*}$ \\
$5.0-6.99$ & $0.95^{*}$ & $0.84^{* *}$ & $-0.04^{\#}$ \\
Total & $0.88^{*}$ & $0.68^{* * *}$ & $0.90^{*}$ \\
Total for all branches & $0.94^{*}$ & $0.77^{* *}$ & $0.94^{*}$ \\
Cones & $0.80^{* *}$ & $0.70^{* * * *}$ & $0.83^{* *}$ \\
Live foliage & $0.87^{*}$ & $0.79^{* *}$ & $0.84^{* *}$ \\
Stem ( $\geq 7.0$ cm in diameter $)$ & $0.97^{*}$ & $0.85^{* *}$ & $0.94^{*}$ \\
Total tree biomass & $0.97^{*}$ & $0.84^{* *}$ & $0.95^{*}$ \\
\hline
\end{tabular}

Correlation is significant at $* P<0.0005$; $* * P<0.005$; $* * * P<0.025 ; * * * * P<0.05$; ${ }^{\#}$ variables are not significantly correlated $(P>0.05)$
We developed the same regressions for the dry Yartsevo and Govorkovo sites because they have similar biomass and separate regressions for the higher-moisture Khrebtovo site. Figure 4 shows illustrative plots of several of these regression relationships and the data points used for developing them. For ease of interpretation, these are plotted using the nontransformed variables rather than the $\log _{10}$ values that we used for the regressions.

The total tree biomass on each plot was calculated based on Eq. 2 and tree diameter size distribution determined from the PCQ plots. Aboveground stand biomass of living trees varied from 8.0 to $16.0 \mathrm{~kg} / \mathrm{m}^{2}$ among our plots (Table 4). Trees with higher DBH (32 and $36 \mathrm{~cm} \mathrm{DBH),} \mathrm{which} \mathrm{were}$ common on our site, accounted for most of the tree biomass over the site. Nine of 13 experimental plots had dead standing trees, ranging from 12 to $45 \mathrm{~cm}$ in DBH and accounting for $1-15 \%$ from the total stand basal area (Table 1). Their aboveground biomass accounted for $0.12-0.18 \mathrm{~kg} / \mathrm{m}^{2}$ over experimental plots (Table 4). The largest component of the living aboveground tree biomass was the stems (up to 80\%) followed by living branches (10.6-13.2\%), dead branches (2.1-5.4\%), and needles (3.4-4.9\%). Dead trees accounted for no more than $2 \%$ of the total aboveground stand biomass. Total stand biomass on the study plots in the southern taiga was higher than in the central taiga, most likely due to more favorable climate conditions, higher stand productivity and density (Table 1). However, as the stand in the southern taiga contained younger trees with smaller diameters (DBH was $25 \%$ less), the difference in stand biomass between our southern and central taiga sites was only $12 \%$.

As mentioned in the "Introduction", crown fires are relatively rare on Scots pine sites in Siberia. This rarity is attributable to the generally low stand density, lack of ladder fuels, and high crowns, which are particularly characteristic of dry Scots pine forests. The typical height to live crown of the PCQ trees was $11.1 \pm 0.3 \mathrm{~m}$ in the central taiga and $12.5 \pm 0.3 \mathrm{~m}$ in the southern taiga (Table 1 ). The difference in height to crown is attributed to the greater degree of self-pruning in the higher-density southern taiga stands. If a crown fire were to occur in these forests, the fire would normally only consume the foliage and living and dead branches up to $1.0 \mathrm{~cm}$ in diameter (Kurbatsky 1970). This category would only account for $0.60-1.35 \mathrm{~kg} / \mathrm{m}^{2}$ on our experimental plots (Table 4). The remaining portions of a living tree are usually too large, moist, and widely spaced to be consumed, especially given the normally short residence time of a crown fire.

While not a major component of our stands, small pockets of Scots pine saplings ( $>1.5 \mathrm{~m}$ tall), caused when gaps were created by past fires that killed the mature trees and allowed full sunlight to reach the ground, were scattered irregularly across many of the plots. These pockets occupied from 0.01 to 0.08 ha $(0.3-2.0 \%)$ in Yartsevo on seven of nine plots and 0.31 ha on Plot 2 in Govorkovo, but not at Khrebtovo. The Scots pine saplings in these pockets varied across the experimental plots from averages of $2.1-5.3 \mathrm{~cm}$ 
Table 3 Coefficients used to determine the logarithm of biomass of individual trees and their components as related to the logarithm of DBH on Scots pine forest sites (see Eq. 2 in the text)

\begin{tabular}{|c|c|c|c|c|c|c|}
\hline Biomass component & $B_{\mathrm{o}}$ & $b_{1}$ & $b_{2}$ & $R^{2}$ & SE & $P$ \\
\hline \multicolumn{7}{|l|}{ Yartsevo and Govorkovo sites } \\
\hline Total & -0.9066 & 2.2041 & 0.0752 & 0.972 & 0.121 & 0.000 \\
\hline Stem & -1.3631 & 2.7783 & -0.1477 & 0.966 & 0.137 & 0.000 \\
\hline Live branch total & -0.7189 & 0.1451 & 0.9481 & 0.934 & 0.192 & 0.000 \\
\hline Dead branch total & -1.0344 & -1.4926 & 1.9368 & 0.962 & 0.187 & 0.000 \\
\hline Class 1 live branches + needles & -0.6801 & 0.5901 & 0.4968 & 0.914 & 0.163 & 0.000 \\
\hline Class 2 live branches & -1.6790 & 1.3153 & 0.1873 & 0.890 & 0.185 & 0.000 \\
\hline Class 1 dead branches but for $\log D>2.2$, let $\log D=2.2$ & -2.8237 & 2.8288 & -0.6276 & 0.759 & 0.224 & 0.001 \\
\hline Class 2 dead branches but for $\log D>1.5$, let $\log D=1.5$ & -11.9825 & 15.7803 & -5.1084 & 0.908 & 0.119 & 0.000 \\
\hline Needles & -1.0081 & 1.0254 & 0.2675 & 0.900 & 0.166 & 0.000 \\
\hline \multicolumn{7}{|l|}{ Khrebtovo site } \\
\hline Total & -1.2726 & 3.1282 & -0.4902 & 0.993 & 0.058 & 0.003 \\
\hline Stem & -1.3991 & 3.2079 & -0.5265 & 0.993 & 0.060 & 0.004 \\
\hline Live branch total & -2.8276 & 3.7277 & -0.6098 & 0.995 & 0.060 & 0.003 \\
\hline Dead branch total & -1.9931 & 1.3171 & 0.3298 & 0.937 & 0.169 & 0.031 \\
\hline Class 1 live branches + needles but for $\log D>2.4$, let $\log D=2.4$ & -1.9943 & 2.9749 & -0.6168 & 0.972 & 0.096 & 0.014 \\
\hline Class 2 live branches & -2.6429 & 2.5990 & -0.3473 & 0.991 & 0.059 & 0.004 \\
\hline Class 1 dead branches & -1.4786 & 0.7081 & 0 & 0.173 & 0.348 & 0.268 \\
\hline Class 2 dead branches & -2.5832 & 1.4968 & 0 & 0.324 & 0.582 & 0.186 \\
\hline Needles & -1.9880 & 2.6700 & -0.4877 & 0.976 & 0.086 & 0.011 \\
\hline
\end{tabular}

$R^{2}$ is the adjusted multiple $R^{2}$ for each polynomial regression. SE is the standard error of the predicted logarithm of biomass components for any individual tree regardless of diameter. $P$ is the significance level for the regression. Data are from destructive sampling of 16 trees

in DBH and 4.0-7.6 $\mathrm{m}$ in height. The total biomass for this regeneration varied from 0.18 to $1.59 \mathrm{~kg} / \mathrm{m}^{2}$ in the pockets, but was very small at the plot level $\left(0.006-0.101 \mathrm{~kg} / \mathrm{m}^{2}\right.$ on plots where sapling pockets occurred; Table 5). These conifer regeneration pockets can be an important ladder fuel to initiate torching or crown fire in the canopy trees under high wind conditions.

\section{Surface and ground fuels}

The living surface ground cover on the experimental plots reflected the microsite conditions on the plot. The total projected cover of ground vegetation depended on stand canopy closure. The surface vegetation layer had a well-pronounced structure, which was controlled by small (1-2 m) variations in relief as well as impacts from the last wildfire. Moist microdepressions were occupied by a Ledum sp.-V. vitisidaea community.

The total projected cover of the herb-grass-small shrub layer at Yartsevo ranged from 15 to $40 \%$. The height of this layer was typically $20-35 \mathrm{~cm}$. The layer was dominated by small shrubs, whose proportions varied significantly depending on growing conditions: $V$. vitis-idaea dominated on better drained sites (ecotopes); Vaccinium myrtillus L. dominated mesic sites, Ledum palustre L. dominated wetter sites, and small bog shrubs and Sphagnum dominated very wet sites. Mosses (60-100\% of projected cover) were dominated by $P$. schreberi. Although lichens occurred on all plots, the projected cover varied widely $(20-100 \%)$ with complete dominance on sites severely burned by previous wildfires, where low tree density allowed more full sunlight to reach the ground leading to lower soil moisture.

In Govorkovo, the projected cover of the grass-small shrub layer, which was dominated by $V$. vitis-idaea, $V$. myrtillus, and Ledum palustre varied from 30 to $80 \%$ of the total plot area depending on stand canopy closure. Feather mosses, mainly P. schreberi, covered up to $100 \%$ of the plot areas. Lichens, dominated by Cladonia rangiferina, covered up to $40 \%$ of the plots. On the Khrebtovo sites, lichens (mainly $C$. rangiferina) covered less than $1 \%$ of the plots. Well-developed mosses, mainly Pleurozeum schreberi and Hylocomium splendens (Hedw.) B. S. G., formed a layer 5-7 $\mathrm{cm}$ high covering up to $100 \%$ of the plot areas. The grass-small shrub layer was dominated by small shrubs $(V$. vitis-idaea, V. myrtillus) and herbs (Calamagrostis arundinacea (L.) Roth., Iris ruthenica Ker-Gawl., Pyrola rotundifolia L., Carex macroura Meinch.).

The types of surface vegetation cover were similar across the experimental plots in different sites. However, the relative importance of individual cover types differed 

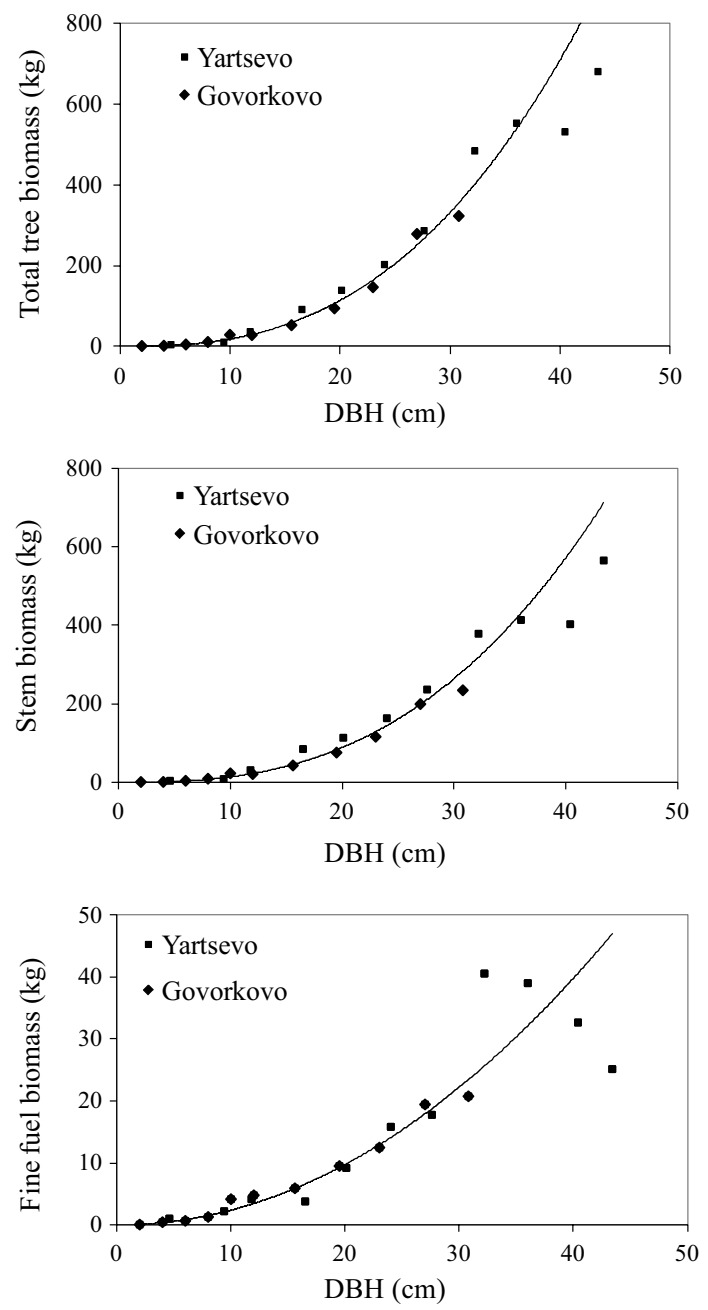

Fig. 4 Plots of data and regressions used to estimate biomass components of individual Scots pine trees based on diameter at breast height $(\mathrm{DBH})$. We used the same regressions for the dry Yartsevo and Govorkovo sites because they have similar biomass. Note the difference in vertical scale for the fine fuel biomass, which included small diameter (Class 1) branches and foliage

among plots, which is clear from the proportions of structural elements of the ground vegetation layer. The distribution of a few major cover types (e.g., feather moss and lichen) reflects differences in microsite moisture regimes. The transitional ground cover types (e.g., whortleberry, lichen, feather moss) occurred in most cases as a result of the influence of ecosystem (or vegetation) factors related to the influence of the previous fire and edaphic factors. In Yartsevo and Govorkovo, fewer than 15 herb and small shrub species were found, but up to 10 varieties of feather moss and lichen species were noted. A similarity coefficient (Vasilevich 1969) of 60\% found for the plots suggested that all the plots are floristically comparable (Kovaleva et al. 2011). In the more mesic Khrebtovo site, there were 28 species of herbs and shrubs, and only three species of lichens, which grew on rotten woody debris rather than directly on the forest floor.

The total surface and ground fuel loading (Table 6), including herbs and small shrubs, litter, moss, lichen, duff (F and $\mathrm{H}$ layers), and DDWF varied from 4.0 to $6.2 \mathrm{~kg} / \mathrm{m}^{2}$ in the central taiga and from 3.8 to $5.0 \mathrm{~kg} / \mathrm{m}^{2}$ in the southern taiga. Although stands are generally more productive in the southern taiga, fuel loads in the central taiga exceed those in the southern taiga by $13 \%(P<0.1)$, which might be a result of lower decomposition rates in northern sites (Johansson 1994). Variability in fuel loading among the plots within the same site location was related to the impact and recovery time since the last wildfire, microsite variability, and the mosaic distribution (heterogeneity) of living ground vegetation that establishes after fires (Ivanova and Perevoznikova 1996). Mosses, lichens and duff accounted for the major proportion (58.1-89.1\%) of the total surface and ground fuel loading with small shrubs and herbs, litter, and dead down woody debris making up $0.3-1.7 \%$, 1.6-6.3\%, and 8.3-34.7\%, respectively (Table 6). Mosses and lichens accounted for $0.7-1.7 \mathrm{~kg} / \mathrm{m}^{2}$. Duff loading was $71-158 \%$ higher than that of moss and lichen. While litter, lichen and moss are commonly consumed almost completely during most fires even of low to moderate severity in Scots pine forest, the consumption of the duff layer depends on its moisture content at the time of burning. Kurbatsky (1962) stated that where the feather moss is moist, or dry only at the tips, little to no duff consumption occurs.

Surface and ground fuel loading varied both within and between individual plots. The within-plot coefficient of variation ranged from 24 to $46 \%$. With this in-plot variation, 25 sample points provided sufficient accuracy (standard error $5.1-9.1 \%$ of the mean). The coefficient of variation for the herb/small shrub layer, with the latter as the dominant component, was high (50-170\%) due to the non-uniform distribution and low fuel loading (up to only $0.07 \mathrm{~kg} / \mathrm{m}^{2}$ ) of this component of the fuel-vegetation complex.

The relatively small amount of litter $\left(<0.3 \mathrm{~kg} / \mathrm{m}^{2}\right)$ on the Yartsevo site was dominated by pine cones $(43 \%)$ and needles (32\%) (Fig. 5). Bark contributed 24\% and cured herbs including grasses and small shrubs only $1 \%$ to the litter biomass. The dominance of cones in the litter loading at this site could be a result of more prolific pine cone production that can occur at low stand densities (Pobedinsky 1979) as well as lower rates of the decomposition process in the central taiga compared to the southern taiga (Vedrova 2002). In Govorkovo, litter loading was dominated by needles (47\%), but in Khrebtovo, leaves of the well-developed understory layer (mainly alder) contributed the most to the total litter loads $(40 \%)$. Higher litter biomass $(5-15 \%$ of the total ground and surface fuel load) is often found where Scots pine occurs on more productive sites farther to the south (Ivanova 2005). 
Table 4 Aboveground stand biomass and biomass of individual crown components for living trees on our sample plots

\begin{tabular}{|c|c|c|c|c|c|c|c|c|c|c|}
\hline \multirow[t]{4}{*}{ Plot } & \multicolumn{9}{|l|}{ Living biomass } & \multirow{4}{*}{$\begin{array}{l}\text { Total dead } \\
\text { biomass }(\mathrm{kg} / \\
\left.\mathrm{m}^{2}\right)\end{array}$} \\
\hline & \multirow[t]{3}{*}{ Total $\left(\mathrm{kg} / \mathrm{m}^{2}\right)$} & \multicolumn{8}{|c|}{ Crown components } & \\
\hline & & \multicolumn{2}{|l|}{ Needles } & \multicolumn{2}{|c|}{$\begin{array}{l}\text { Needles, living and } \\
\text { dead branches up to } \\
0.99 \mathrm{~cm} \text { in diameter }\end{array}$} & \multicolumn{2}{|c|}{ Live branches } & \multicolumn{2}{|c|}{ Dead branches } & \\
\hline & & $\left(\mathrm{kg} / \mathrm{m}^{2}\right)$ & $(\%)$ & $\left(\mathrm{kg} / \mathrm{m}^{2}\right)$ & $(\%)$ & $\left(\mathrm{kg} / \mathrm{m}^{2}\right)$ & $(\%)$ & $\left(\mathrm{kg} / \mathrm{m}^{2}\right)$ & $(\%)$ & \\
\hline \multicolumn{11}{|c|}{ Central taiga (Yartsevo site) } \\
\hline 2 & $8.19 \pm 1.55$ & $0.29 \pm 0.05$ & 3.5 & $0.62 \pm 0.09$ & 7.6 & $1.01 \pm 0.19$ & 12.3 & $0.34 \pm 0.07$ & 4.2 & 0 \\
\hline 3 & $8.01 \pm 1.27$ & $0.28 \pm 0.04$ & 3.5 & $0.60 \pm 0.07$ & 7.5 & $1.01 \pm 0.15$ & 12.6 & $0.36 \pm 0.05$ & 4.5 & $0.12 \pm 0.01$ \\
\hline 4 & $12.08 \pm 1.49$ & $0.42 \pm 0.05$ & 3.5 & $0.90 \pm 0.08$ & 7.5 & $1.56 \pm 0.21$ & 12.9 & $0.62 \pm 0.12$ & 5.1 & $0.18 \pm 0.02$ \\
\hline 6 & $14.54 \pm 1.60$ & $0.53 \pm 0.06$ & 3.6 & $1.13 \pm 0.10$ & 7.8 & $1.75 \pm 0.19$ & 12.0 & $0.57 \pm 0.07$ & 3.9 & $0.14 \pm 0.01$ \\
\hline 13 & $11.49 \pm 1.80$ & $0.42 \pm 0.07$ & 3.7 & $0.89 \pm 0.11$ & 7.7 & $1.42 \pm 0.22$ & 12.4 & $0.50 \pm 0.09$ & 4.4 & 0 \\
\hline 14 & $12.50 \pm 2.12$ & $0.43 \pm 0.08$ & 3.4 & $0.92 \pm 0.12$ & 7.4 & $1.65 \pm 0.28$ & 13.2 & $0.68 \pm 0.12$ & 5.4 & 0 \\
\hline 19 & $8.86 \pm 1.16$ & $0.36 \pm 0.04$ & 4.1 & $0.74 \pm 0.07$ & 8.4 & $1.06 \pm 0.16$ & 12.0 & $0.38 \pm 0.10$ & 4.3 & $0.15 \pm 0.02$ \\
\hline 20 & $15.95 \pm 3.16$ & $0.65 \pm 0.12$ & 4.1 & $1.35 \pm 0.19$ & 8.5 & $1.79 \pm 0.36$ & 11.2 & $0.50 \pm 0.11$ & 3.1 & $0.12 \pm 0.01$ \\
\hline 21 & $12.39 \pm 1.51$ & $0.48 \pm 0.06$ & 3.9 & $1.00 \pm 0.09$ & 8.1 & $1.42 \pm 0.18$ & 11.5 & $0.40 \pm 0.06$ & 3.2 & 0 \\
\hline Average & $11.56 \pm 0.92$ & $0.43 \pm 0.04$ & 3.7 & $0.91 \pm 0.08$ & 7.8 & $1.41 \pm 0.10$ & 12.2 & $0.48 \pm 0.04$ & 4.2 & $0.08 \pm 0.03$ \\
\hline \multicolumn{11}{|c|}{ Southern taiga (Govorkovo and Khrebtovo sites) } \\
\hline 1 & $15.66 \pm 0.17$ & $0.64 \pm 0.06$ & 4.1 & $1.32 \pm 0.10$ & 8.4 & $1.74 \pm 0.20$ & 11.1 & $0.46 \pm 0.07$ & 2.9 & $0.06 \pm 0.01$ \\
\hline 2 & $12.35 \pm 0.20$ & $0.50 \pm 0.08$ & 4.0 & $1.04 \pm 0.12$ & 8.4 & $1.39 \pm 0.24$ & 11.3 & $0.38 \pm 0.08$ & 3.1 & $0.07 \pm 0.01$ \\
\hline 3 & $12.65 \pm 1.21$ & $0.56 \pm 0.05$ & 4.4 & $1.07 \pm 0.08$ & 8.5 & $1.43 \pm 0.14$ & 11.3 & $0.30 \pm 0.03$ & 2.4 & $0.11 \pm 0.01$ \\
\hline 5 & $11.36 \pm 1.22$ & $0.56 \pm 0.06$ & 4.9 & $1.07 \pm 0.09$ & 9.4 & $1.20 \pm 0.13$ & 10.6 & $0.24 \pm 0.03$ & 2.1 & $0.09 \pm 0.01$ \\
\hline Average & $13.01 \pm 0.93$ & $0.57 \pm 0.03$ & 4.3 & $1.13 \pm 0.07$ & 8.7 & $1.44 \pm 0.11$ & 11.1 & $0.35 \pm 0.05$ & 2.7 & $0.06 \pm 0.02$ \\
\hline
\end{tabular}

Percentages for separate crown components were calculated relative to the total living stand biomass on each plot. Data are means for 25 samples per plot. All biomass values are shown as mean \pm standard error

The total ground fuel load on the more mesic pine/ moss forests in central Siberia was $40-55 \%$ higher than we observed. In birch-pine forests with grasses as dominant ground cover, ground fuel loads varied from 1.8 to $2.5 \mathrm{~kg} / \mathrm{m}^{2}$ (Buryak et al. 2003), 30-55\% lower than loads at our Scots pine sites. In the northern taiga spruce forest dominated by moss vegetation, ground fuels loads can reach $6.8 \mathrm{~kg} / \mathrm{m}^{2}$

Table 5 Characteristics and biomass of young coniferous regeneration over $1.5 \mathrm{~m}$ tall in pockets across the study plots

\begin{tabular}{|c|c|c|c|c|c|}
\hline \multirow[t]{2}{*}{ Plot } & \multirow{2}{*}{$\begin{array}{l}\text { Average } \\
\text { DBH }(\mathrm{cm})\end{array}$} & \multirow{2}{*}{$\begin{array}{l}\text { Average } \\
\text { height }(\mathrm{m})\end{array}$} & \multirow{2}{*}{$\begin{array}{l}\text { Density } \\
\text { (stems/ha) }\end{array}$} & \multicolumn{2}{|c|}{ Total biomass $\left(\mathrm{kg} / \mathrm{m}^{2}\right)$} \\
\hline & & & & Plot level & In pockets \\
\hline \multicolumn{6}{|c|}{ Central taiga (Yartsevo site) } \\
\hline 2 & 3.7 & 6.2 & 25 & 0.015 & 0.178 \\
\hline 3 & 5.3 & 7.0 & 12 & 0.010 & 0.994 \\
\hline 4 & 3.9 & 6.3 & 17 & 0.010 & 0.616 \\
\hline 13 & 4.6 & 6.3 & 10 & 0.006 & 1.473 \\
\hline 14 & 2.5 & 4.5 & 11 & 0.006 & 0.564 \\
\hline 19 & 5.1 & 7.6 & 18 & 0.014 & 0.334 \\
\hline 21 & 2.1 & 4.0 & 18 & 0.008 & 1.589 \\
\hline \multicolumn{6}{|c|}{ Southern taiga (Govorkovo site) } \\
\hline 2 & 2.1 & 3.8 & 1602 & 0.101 & 1.287 \\
\hline
\end{tabular}

(Marchenko and Karlov 1961). Both ground and surface fuel loads in mixed larch-pine forest with a dark-coniferous subcanopy layer in the Angara region are up to 65\% higher than on the sites reported on here (Zhila et al. 2011). For boreal forests of Canada, Stocks and Hartley (1995) reported surface and ground fuel loads in an Ontario mature jack pine forest of $7.9 \mathrm{~kg} / \mathrm{m}^{2}$, almost twice as high as on our study plots.

We observed a strong relationship between ground fuel depth and ground fuel loading (Fig. 6). While fuel loads up to $6 \mathrm{~cm}$ depth in the central and southern taiga have similar relations with fuel depth, fuel loads $>6 \mathrm{~cm}$ in the southern taiga are typically $10-25 \%$ lower than loads in the central taiga, perhaps a result of the higher rate of the decomposition in southern sites (Vedrova 2002). Ground fuel loading and stand basal area were highly correlated, but only for the plots situated on drier soils where lichen dominated the ground cover (Fig. 7).

The DDWF load within individual plots for our study area had a coefficient of variation ranging from 187 to $302 \%$. This variation resulted from the non-uniform distribution of fuels across the study area and differences in the various diameter size class loadings (Table 7). DDWF $\geq 7 \mathrm{~cm}$ in diameter accounted for $90 \%$ of the DDWF load. However, these large 
Table 6 Surface and ground fuel loadings for central and southern taiga Scots pine stands in Siberia

\begin{tabular}{|c|c|c|c|c|c|c|c|c|c|c|c|}
\hline \multirow[t]{2}{*}{ Plot } & \multicolumn{2}{|c|}{ Herbs, small shrubs } & \multicolumn{2}{|l|}{ Litter } & \multicolumn{2}{|c|}{ Moss, lichen, duff } & \multicolumn{2}{|l|}{ Subtotal } & \multicolumn{2}{|c|}{ Dead down wood } & \multirow{2}{*}{$\begin{array}{l}\text { Total fuels } \\
\left(\mathrm{kg} / \mathrm{m}^{2}\right)\end{array}$} \\
\hline & $\left(\mathrm{kg} / \mathrm{m}^{2}\right)$ & $(\%)$ & $\left(\mathrm{kg} / \mathrm{m}^{2}\right)$ & $(\%)$ & $\left(\mathrm{kg} / \mathrm{m}^{2}\right)$ & $(\%)$ & $\left(\mathrm{kg} / \mathrm{m}^{2}\right)$ & $(\%)$ & $\left(\mathrm{kg} / \mathrm{m}^{2}\right)$ & $(\%)$ & \\
\hline \multicolumn{12}{|c|}{ Central taiga (Yartsevo site) } \\
\hline 2 & $0.02 \pm 0.01$ & 0.3 & $0.10 \pm 0.01$ & 1.6 & $4.84 \pm 0.26$ & 77.6 & $4.96 \pm 0.27$ & 79.5 & $1.28 \pm 0.30$ & 20.5 & 6.24 \\
\hline 3 & $0.02 \pm 0.01$ & 0.4 & $0.18 \pm 0.02$ & 3.3 & $4.32 \pm 0.27$ & 79.7 & $4.52 \pm 0.26$ & 83.4 & $0.90 \pm 0.31$ & 16.6 & 5.42 \\
\hline 4 & $0.05 \pm 0.01$ & 1.3 & $0.16 \pm 0.03$ & 4.0 & $2.97 \pm 0.23$ & 74.3 & $3.18 \pm 0.28$ & 79.5 & $0.82 \pm 0.30$ & 20.5 & 4.00 \\
\hline 6 & $0.04 \pm 0.01$ & 0.9 & $0.18 \pm 0.02$ & 4.1 & $3.72 \pm 0.18$ & 84.4 & $3.94 \pm 0.18$ & 89.3 & $0.47 \pm 0.18$ & 10.7 & 4.41 \\
\hline 13 & $0.06 \pm 0.01$ & 1.2 & $0.29 \pm 0.06$ & 6.0 & $2.83 \pm 0.26$ & 58.1 & $3.18 \pm 0.29$ & 65.3 & $1.69 \pm 0.56$ & 34.7 & 4.87 \\
\hline 14 & $0.07 \pm 0.01$ & 1.7 & $0.26 \pm 0.03$ & 6.3 & $2.86 \pm 0.20$ & 68.9 & $3.19 \pm 0.21$ & 76.9 & $0.96 \pm 0.36$ & 23.1 & 4.15 \\
\hline 19 & $0.05 \pm 0.01$ & 1.2 & $0.18 \pm 0.02$ & 4.4 & $3.03 \pm 0.22$ & 73.4 & $3.26 \pm 0.22$ & 78.9 & $0.87 \pm 0.35$ & 21.1 & 4.13 \\
\hline 20 & $0.02 \pm 0.01$ & 0.4 & $0.11 \pm 0.01$ & 2.3 & $4.17 \pm 0.32$ & 85.5 & $4.30 \pm 0.32$ & 88.1 & $0.58 \pm 0.21$ & 11.9 & 4.88 \\
\hline 21 & $0.03 \pm 0.01$ & 0.6 & $0.11 \pm 0.02$ & 2.1 & $4.72 \pm 0.44$ & 89.1 & $4.86 \pm 0.44$ & 91.7 & $0.44 \pm 0.14$ & 8.3 & 5.30 \\
\hline Average & $0.04 \pm 0.01$ & 0.8 & $0.17 \pm 0.02$ & 3.5 & $3.72 \pm 0.27$ & 77.2 & $3.93 \pm 0.25$ & 81.5 & $0.89 \pm 0.13$ & 18.5 & $4.82 \pm 0.25$ \\
\hline \multicolumn{12}{|c|}{ Southern taiga (Govorkovo and Khrebtovo sites) } \\
\hline 1 & $0.03 \pm 0.01$ & 0.7 & $0.16 \pm 0.03$ & 3.8 & $3.48 \pm 0.26$ & 81.9 & $3.67 \pm 0.26$ & 86.4 & $0.58 \pm 0.15$ & 13.6 & 4.25 \\
\hline 2 & $0.06 \pm 0.01$ & 1.2 & $0.11 \pm 0.02$ & 2.2 & $3.93 \pm 0.37$ & 78.3 & $4.10 \pm 0.37$ & 81.7 & $0.92 \pm 0.25$ & 18.3 & 5.02 \\
\hline 3 & $0.04 \pm 0.01$ & 1.0 & $0.19 \pm 0.02$ & 4.9 & $2.48 \pm 0.25$ & 63.4 & $2.71 \pm 0.25$ & 69.3 & $1.20 \pm 0.22$ & 30.7 & 3.91 \\
\hline 5 & $0.05 \pm 0.01$ & 1.3 & $0.18 \pm 0.01$ & 4.8 & $2.41 \pm 0.18$ & 64.1 & $2.64 \pm 0.18$ & 70.2 & $1.12 \pm 0.29$ & 29.8 & 3.76 \\
\hline Average & $0.05 \pm 0.01$ & 1.1 & $0.16 \pm 0.02$ & 3.8 & $3.08 \pm 0.38$ & 73.1 & $3.28 \pm 0.36$ & 78.0 & $0.96 \pm 0.14$ & 22.7 & $4.21 \pm 0.26$ \\
\hline
\end{tabular}

Data for dead down woody debris are means for 49 sample lines $(5 \mathrm{~m}$ each) per plot; for all others, means are for $25 \mathrm{samples}(20 \times 25 \mathrm{~cm}$ each) per plot. All load values are means \pm standard error

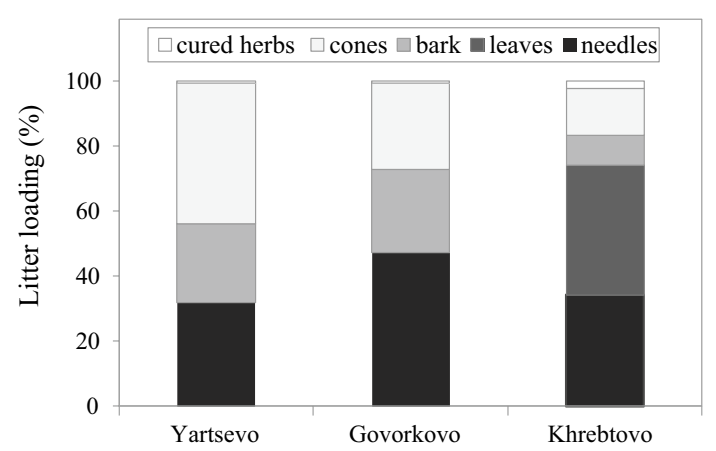

Fig. 5 Composition of litter loading on different study sites

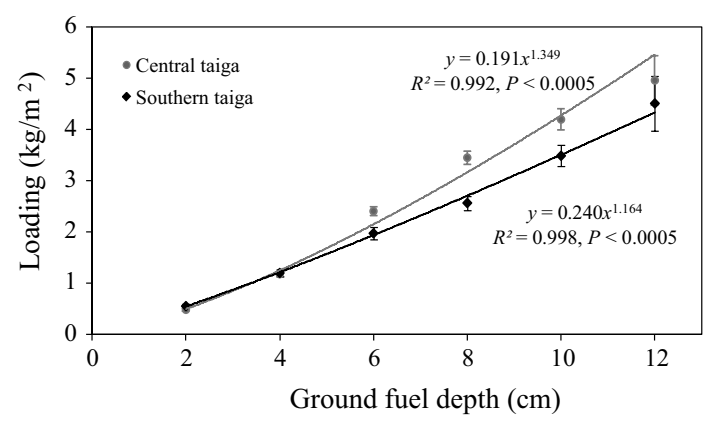

Fig. 6 Relationships between ground fuel depths and loadings in Scots pine stands of the central and southern taiga. Means for the central taiga are based on data from 199 sample quadrats and 88 sample quadrats for the southern taiga

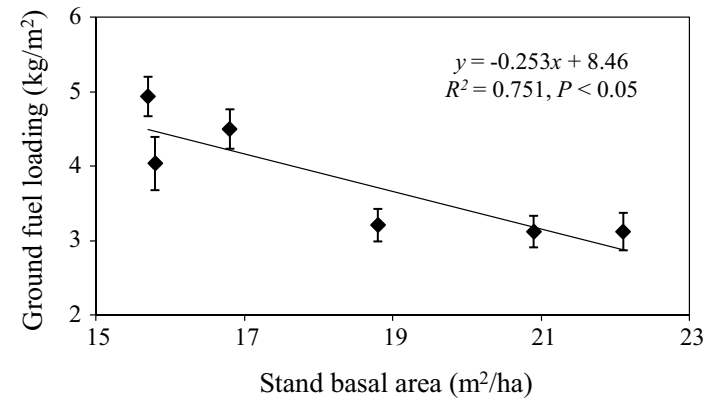

Fig. 7 Relationship between ground fuel loading and stand basal area for the dry plots with lichens dominating the ground cover (Plots 2, 3, 13, and 14 in Yartsevo; Plot 2 in Govorkovo). Ground fuels include litter, live lichens, mosses and duff

pieces were widely scattered and present on only $22 \pm 3 \%$ of the line intersects. The highest DDWF load for pieces $<7 \mathrm{~cm}$ in diameter in the $1.0-2.99 \mathrm{~cm}$ diameter size class (up to $11 \%$ of the total). A significant relationship $(R=-0.64$, $P<0.05)$ between the loading of down woody debris and stand basal area at our Yartsevo site in the central taiga (Fig. 8) showed that DDWF loads are negatively correlated with BA values, perhaps a result of old trees dying and their transition from the category "stand" to "down woody debris" which accumulates on the ground due to low decomposition rates (Vedrova 2002). We did not find the same relationship for plots in the southern taiga because they are represented 
Table 7 Down woody fuel loading $\left(\mathrm{kg} / \mathrm{m}^{2}\right)$, by diameter size class for the central and southern taiga Scots pine stands in Siberia

\begin{tabular}{|c|c|c|c|c|c|c|c|c|}
\hline \multirow[t]{3}{*}{ Plot } & \multicolumn{8}{|c|}{ Diameter size class $(\mathrm{cm})$} \\
\hline & \multirow[t]{2}{*}{$0.0-0.49$} & \multirow[t]{2}{*}{$0.5-0.99$} & \multirow[t]{2}{*}{$1.0-2.99$} & \multirow[t]{2}{*}{$3.0-4.99$} & \multirow[t]{2}{*}{$5.0-6.99$} & \multicolumn{3}{|l|}{$\geq 7.0$} \\
\hline & & & & & & Solid & Rotten & Total \\
\hline \multicolumn{9}{|c|}{ Central taiga (Yartsevo site) } \\
\hline 2 & $0.02 \pm 0.002$ & $0.02 \pm 0.002$ & $0.03 \pm 0.01$ & $0.04 \pm 0.01$ & $0.05 \pm 0.02$ & $0.81 \pm 0.28$ & $0.31 \pm 0.14$ & $1.12 \pm 0.30$ \\
\hline 3 & $0.02 \pm 0.002$ & $0.01 \pm 0.002$ & $0.04 \pm 0.01$ & $0.04 \pm 0.02$ & $0.04 \pm 0.02$ & $0.41 \pm 0.26$ & $0.34 \pm 0.16$ & $0.75 \pm 0.30$ \\
\hline 4 & $0.02 \pm 0.002$ & $0.02 \pm 0.002$ & $0.03 \pm 0.005$ & $0.02 \pm 0.01$ & 0 & $0.49 \pm 0.24$ & $0.24 \pm 0.17$ & $0.73 \pm 0.30$ \\
\hline 6 & $0.02 \pm 0.002$ & $0.01 \pm 0.001$ & $0.04 \pm 0.01$ & $0.03 \pm 0.01$ & $0.01 \pm 0.01$ & $0.20 \pm 0.16$ & $0.16 \pm 0.08$ & $0.36 \pm 0.18$ \\
\hline 13 & $0.03 \pm 0.003$ & $0.02 \pm 0.002$ & $0.03 \pm 0.01$ & $0.02 \pm 0.01$ & $0.04 \pm 0.02$ & $0.57 \pm 0.40$ & $0.98 \pm 0.34$ & $1.55 \pm 0.56$ \\
\hline 14 & $0.02 \pm 0.002$ & $0.02 \pm 0.002$ & $0.04 \pm 0.01$ & $0.02 \pm 0.01$ & 0 & $0.30 \pm 0.22$ & $0.56 \pm 0.24$ & $0.86 \pm 0.35$ \\
\hline 19 & $0.02 \pm 0.002$ & $0.01 \pm 0.003$ & $0.03 \pm 0.01$ & $0.01 \pm 0.01$ & $0.03 \pm 0.02$ & $0.60 \pm 0.32$ & $0.17 \pm 0.12$ & $0.77 \pm 0.35$ \\
\hline 20 & $0.04 \pm 0.003$ & $0.03 \pm 0.003$ & $0.05 \pm 0.01$ & $0.01 \pm 0.004$ & $0.01 \pm 0.005$ & $0.23 \pm 0.17$ & $0.21 \pm 0.13$ & $0.44 \pm 0.21$ \\
\hline 21 & $0.03 \pm 0.003$ & $0.02 \pm 0.002$ & $0.05 \pm 0.01$ & $0.01 \pm 0.006$ & 0 & $0.10 \pm 0.07$ & $0.23 \pm 0.12$ & $0.33 \pm 0.14$ \\
\hline Average & $0.02 \pm 0.002$ & $0.02 \pm 0.002$ & $0.04 \pm 0.003$ & $0.02 \pm 0.004$ & $0.02 \pm 0.01$ & $0.41 \pm 0.08$ & $0.36 \pm 0.09$ & $0.77 \pm 0.13$ \\
\hline \multicolumn{9}{|c|}{ Southern taiga (Govorkovo and Khrebtovo sites) } \\
\hline 1 & $0.04 \pm 0.003$ & $0.02 \pm 0.003$ & $0.08 \pm 0.01$ & $0.06 \pm 0.02$ & $0.03 \pm 0.02$ & $0.35 \pm 0.14$ & 0 & $0.35 \pm 0.14$ \\
\hline 2 & $0.04 \pm 0.003$ & $0.02 \pm 0.003$ & $0.07 \pm 0.01$ & $0.03 \pm 0.01$ & $0.06 \pm 0.03$ & $0.70 \pm 0.25$ & 0 & $0.70 \pm 0.25$ \\
\hline 3 & $0.03 \pm 0.001$ & $0.03 \pm 0.002$ & $0.08 \pm 0.01$ & $0.05 \pm 0.02$ & $0.19 \pm 0.05$ & $0.62 \pm 0.21$ & $0.20 \pm 0.06$ & $0.82 \pm 0.21$ \\
\hline 5 & $0.02 \pm 0.001$ & $0.02 \pm 0.002$ & $0.06 \pm 0.01$ & $0.09 \pm 0.02$ & $0.19 \pm 0.05$ & $0.56 \pm 0.25$ & $0.18 \pm 0.10$ & $0.74 \pm 0.28$ \\
\hline Average & $0.03 \pm 0.005$ & $0.02 \pm 0.003$ & $0.07 \pm 0.01$ & $0.06 \pm 0.01$ & $0.12 \pm 0.04$ & $0.56 \pm 0.07$ & $0.10 \pm 0.06$ & $0.65 \pm 0.10$ \\
\hline
\end{tabular}

Data are means for 49 sample lines $(5 \mathrm{~m}$ each) per plot \pm standard error

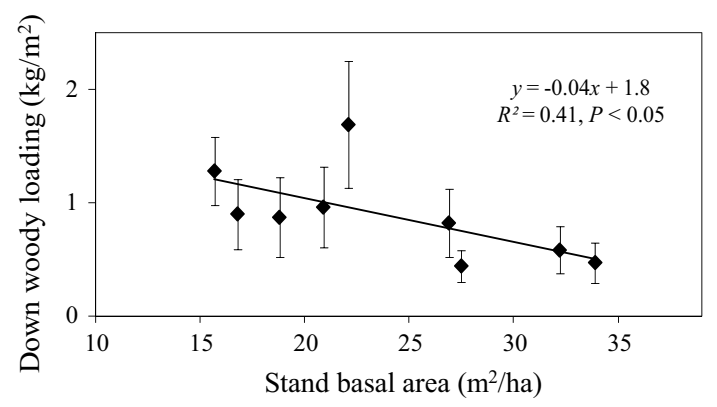

Fig. 8 Relationship between the loading of down woody debris and stand basal area for the central taiga (Yartsevo) plots

by younger stands where the majority of dead trees have DBH of $10-15 \mathrm{~cm}$ compared to the average DBH of $26 \mathrm{~cm}$ in the central taiga plots.

\section{Surface and ground fuel moisture content}

Fuel moisture plays a key role in fire ignition and behavior, since it determines fuel flammability levels and the capability of the fire to spread (carry), which ultimately affects rate of spread and fireline intensity (Kurbatsky 1970). Living herbs/grasses and small shrubs are characterized by relatively high and stable moisture content and are relatively independent of short-term variability in weather conditions compared to dead forest fuels with a similar diameter. Important shrubs (Vaccinium vitis idaea, V. myrtillus, Ledum palustre) on our experimental plots had lower moisture content (110-140\% during the growing season) than herbs (250-350\%), primarily C. arundinacea. The presence of large amounts of herbs and small shrubs can affect the microclimate, as leaf emergence in the spring can reduce air temperature and increase the relative humidity. Such an interaction can increase the fuel moisture in the forest stand, thus reducing fire danger (Kurbatsky and Ivanova 1987). However, herbs and small shrubs on our plots did not contribute substantially to decreasing the natural fire danger, because their total cover was low and distribution was spotty.

Feather moss moisture content on our plots was at least twice that of lichens, since the absorption capacity of lichens is lower compared to that of mosses (Vonsky et al. 1975; Volokitina 1985). Moisture content differences between sun and shady conditions for feather moss (60-70\%) were higher than for lichen (13-44\%). Lichens dried rapidly to below the moisture of extinction after precipitation in the central taiga Scots pine stands. According to Sofronova (1970), the moisture content variability in lichens over $24 \mathrm{~h}$ is about $30 \%$ higher than mosses. The moisture content of lichens and mosses in the Scots pine stands was lowest from 13:00 to 16:00 h; after 17:00 h, fuel moisture content began gradually to increase due to decreased air temperature and increased relative humidity. Moisture content in the upper lichen layer 
can change from between 150 and 160-40\% (the ignition threshold for lichen) over an 8-12-h period (Sofronov et al. 2005). One of our experimental burns on a site with predominantly lichen ground cover was conducted successfully only $2.5 \mathrm{~h}$ after $5 \mathrm{~mm}$ of rain had fallen (McRae et al. 2006), illustrating the importance of rapid changes in moisture content of lichen layers for potential fire ignition and spread.

The correlation coefficient characterizing the relationship between PV-1 and fuel moisture content was -0.55 $(P<0.0005)$ for lichen, and $-0.54(P<0.005)$ for litter (Fig. 9). The moisture content of the litter layer at a given PV-1 value was 5-15\% lower than that of the lichen. This result corresponds to results of Zhukovskaya (1970) in a laboratory after drying fuel samples and is a result of the high moisture absorption capacity of lichen compared to the litter layer. In addition, lichen contacts the wetter mineral layer, while litter is on the top of the surface layer. We found correlations between the moisture content of the P. schreberi layer at different depths with the Russian Fire Danger Index (PV-1), with correlation coefficients ranging between -0.59 and $-0.69(P<0.0005)$ (Fig. 10). Our data agree with layerby-layer moss drying data obtained for Scots pine stands in the northern part of European Russia and in Buryatia (Kurbatsky 1962; Vonsky et al. 1975; Volokitina 1985).

Of the different Canadian Forest Fire Weather Index System codes (DC, BUI, FWI, FFMC), the best correlation with fuel moisture content was found for FWI (from -0.68 to -0.81 ; Fig. 10). McRae et al. (2006) also found the best correlation between fire parameters (fuel consumption,
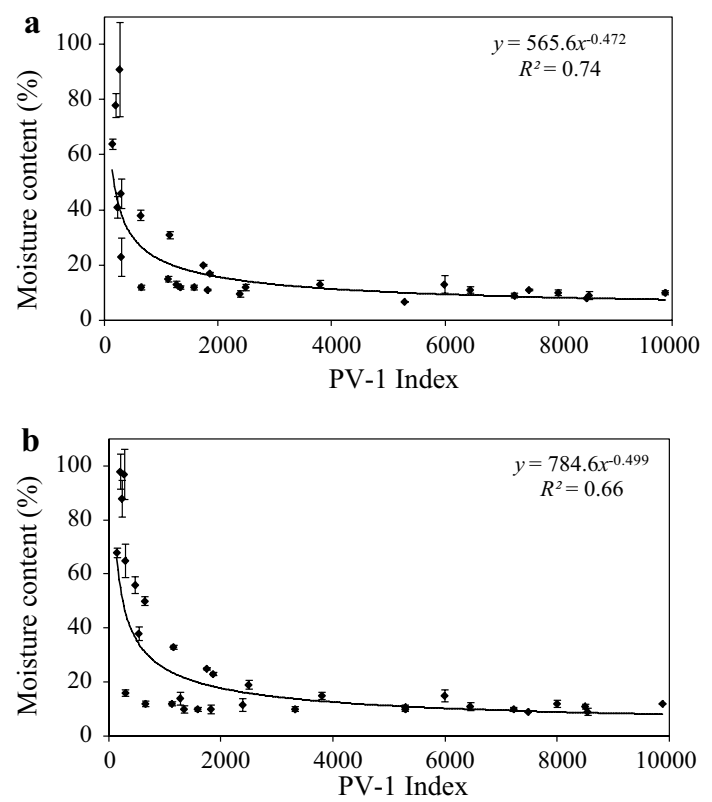

Fig. 9 Fuel moisture differences related to the PV-1 Index (see Eq. 1 in the methods) for the litter (a) and lichen (b) in a Scots pinelichen-feather moss forest stand depth of burn) with FWI in Scots pine forest of Siberia. Based on these relationships between moisture content and PV-1, the moisture contents of hygroscopic litter, lichens, and mosses are clearly dependent on timing and amount of precipitation. The regressions developed could be used to forecast the moisture content of the different fuels depending on the weather conditions and the time when fuels approach the ignition threshold range. Ignition thresholds have been reported to range from 13 to $27 \%$ for litter, $25-40 \%$ for lichens, $10-40 \%$ for mosses, and $16-25 \%$ for cured herbs and grasses (Melekhov 1947; Kurbatsky 1962; Sofronov 1967; Zhukovskaya 1970; Valendik and Gevel 1975; Konev 1977).

\section{Fuel consumption}

Total fuel consumption completeness ranged from 18 to $74 \%$ compared to prefire values (Table 8 ). Grasses and herbs were mainly consumed completely during the fire. Mosses and duff were partially consumed depending on their moisture and fire intensity. The highest fuel consumption $\left(3.08 \mathrm{~kg} / \mathrm{m}^{2}\right)$ was registered for Plot 14 where almost total tree mortality had recently been observed (Kukavskaya et al. 2014). The consumption was similar to the average fuel consumption value of $3.44 \mathrm{~kg} / \mathrm{m}^{2}$ measured during a high-intensity surface and crown fire in a dry Scots pine forest on Bor Island just north of our Yartsevo site (FIRESCAN 1996).

Fuel consumption due to low-intensity fires varied from 0.95 to $1.66 \mathrm{~kg} / \mathrm{m}^{2}$, compared with 1.29 to $2.09 \mathrm{~kg} / \mathrm{m}^{2}$ for fires of moderate-intensity. Low- to moderate-intensity fires result in slightly higher fuel consumption values in the southern taiga compared to central taiga due to more complete fuel combustion, that seems to be a result of drier fuels in southern Siberia. There are just two fires of highintensity - not enough for a valid comparison. However, fuel consumption in the central taiga due to high-intensity fire potentially could be greater due to the greater accumulation of fuels on the ground (Table 6).

\section{Conclusion}

The total aboveground biomass in Scots pine forest types of central and southern Siberia varied widely (from 13.1 to $21.0 \mathrm{~kg} / \mathrm{m}^{2}$ ). Stand biomass was somewhat higher on plots in southern taiga, while ground fuel loads were higher in central taiga. Variations in total biomass among plots within the same study area were due mainly to differences in stand density. Scattered groups of young Scots pine saplings, while not contributing substantially to stand biomass, have the potential to serve as ladder fuels that can carry surface fires into the tree canopy. Needles and small-diameter branches that we would expect might be consumed by crown 

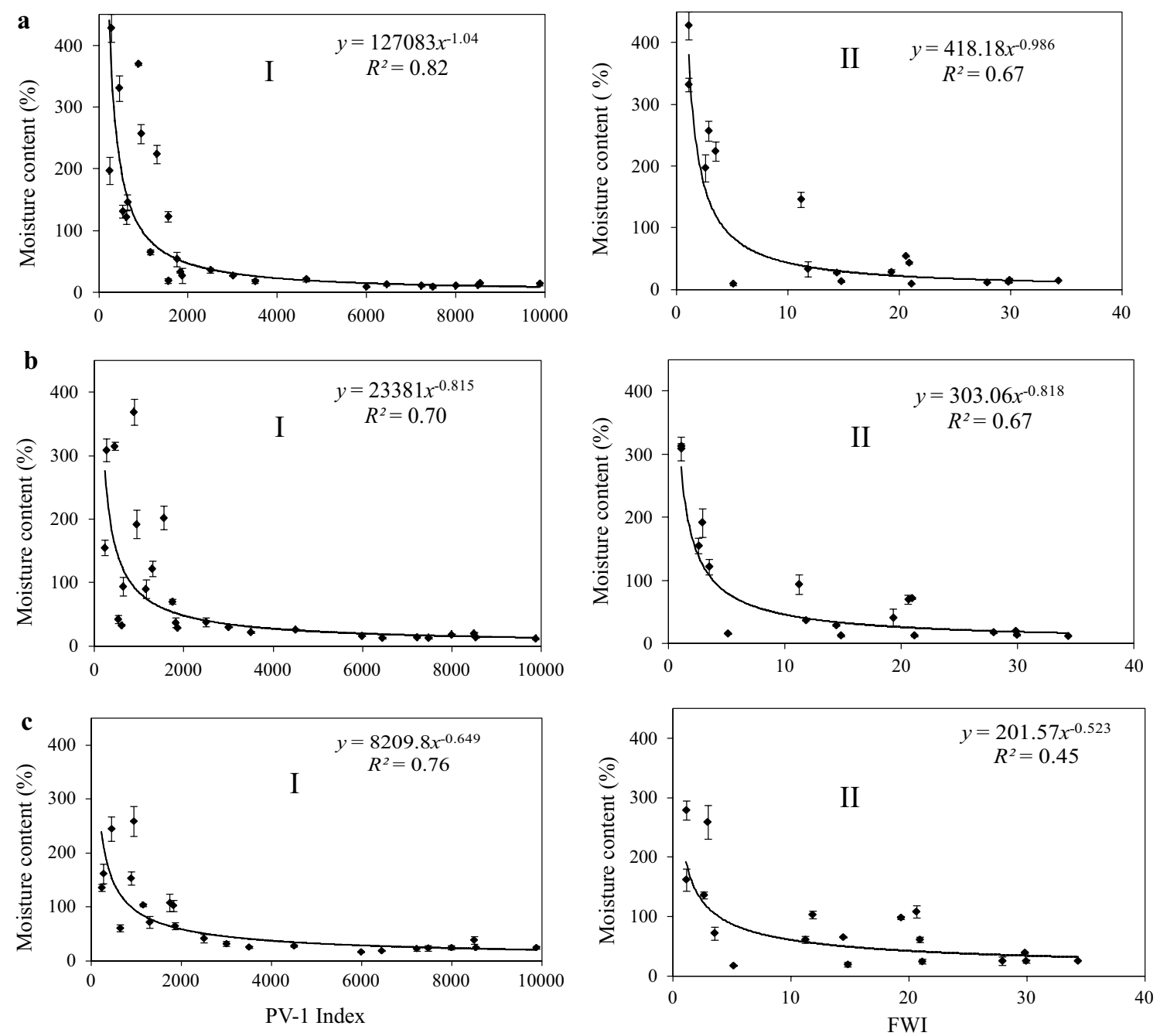

Fig. 10 Fuel moisture changes in feather moss related to the PV-1 Index (I) and Canadian Fire Weather Index (FWI) (II) in a Scots pine-small shrub-feather moss forest stand (a 0-2 cm layer; b 2-4 cm layer; c 4-6 cm layer)

fire, accounted for $18.4 \pm 1.3 \%$ of potentially available fuel, suggesting that crown fuels will not contribute a great deal to overall fuel consumption and emissions over that from moderate to high-severity surface fires.

Surface and ground fuels are the main contributor of fuel consumed during fire in these Scots pine forest types (McRae et al. 2006). Their biomass varied nearly twofold across our central and southern taiga study sites. This layer was composed of widely varying amounts of mosses, lichens, duff, and DDWF (tree stems and branches). The high variability in fuel loads of these key surface and ground fuels indicates the importance of quantifying fuel structure and loads in different areas, rather than using broad regional averages, for input into models of emissions, carbon stocks, and carbon cycle impacts of fire. Fuel consumption due to fires of low to high intensity varied from 0.95 to $3.08 \mathrm{~kg} / \mathrm{m}^{2}$ at our experimental sites.
In high-intensity fires, forest floor materials (primarily surface vegetation, lichens and mosses, duff and DDWF up to 7-cm diameter), live foliage, and small branches may be completely consumed, while large downed material, live tree stems and big branches are usually not. Estimated biomass available to burn varied from 4.5 to $6.5 \mathrm{~kg} / \mathrm{m}^{2}$ across our experimental plots and included the loads of needles and small branches in the tree canopy, surface vegetation, moss, lichen, duff, DDW of up to 7-cm diameter and rotten stems as well as the half of the solid stem loads on the ground. This accounts for about a third of the total aboveground biomass. These fuel loads can support surface fires over a large range of severities, as well as the occasional crown fire in Scots pine-feather moss-lichen forest stands, depending on the burning conditions. After long droughts resulting in high fire hazard (PV-1 > 4000), surface and ground fuels in Scots pine forest can burn very severely, and where ladder fuels such as 
Table 8 Fuel consumption values at the central and southern taiga Scots pine stands in Siberia

\begin{tabular}{|c|c|c|c|c|c|c|c|}
\hline \multirow[t]{2}{*}{ Plot } & \multirow[t]{2}{*}{ Fire intensity } & \multicolumn{6}{|c|}{ Fuel consumption $\left(\mathrm{kg} / \mathrm{m}^{2}\right)$ by fuel types } \\
\hline & & $\begin{array}{l}\text { Grasses } \\
\text { and herbs }\end{array}$ & Litter & $\begin{array}{l}\text { Down } \\
\text { woody } \\
\text { debris }\end{array}$ & $\begin{array}{l}\text { Mosses, } \\
\text { lichen, duff }\end{array}$ & Total & $\begin{array}{l}\text { Difference from } \\
\text { prefire values }(\%)\end{array}$ \\
\hline \multicolumn{8}{|c|}{ Central taiga (Yartsevo site) } \\
\hline 2 & Moderate & 0.02 & 0.10 & 0.03 & 1.19 & 1.34 & 21 \\
\hline 3 & Low & 0.02 & 0.18 & 0.03 & 0.72 & 0.95 & 18 \\
\hline 4 & Low & 0.05 & 0.16 & 0.25 & 0.97 & 1.43 & 36 \\
\hline 6 & Moderate & 0.04 & 0.18 & 0.06 & 1.01 & 1.29 & 29 \\
\hline 13 & Moderate & 0.06 & 0.29 & 0.40 & 1.34 & 2.09 & 43 \\
\hline 14 & High & 0.07 & 0.26 & 0.44 & 2.31 & 3.08 & 74 \\
\hline 19 & Low & 0.05 & 0.18 & 0.06 & 0.80 & 1.09 & 27 \\
\hline 20 & Moderate & 0.02 & 0.11 & 0.17 & 1.05 & 1.35 & 28 \\
\hline 21 & Moderate & 0.03 & 0.11 & 0.13 & 2.12 & 2.39 & 45 \\
\hline \multicolumn{8}{|c|}{ Southern taiga (Govorkovo and Khrebtovo sites) } \\
\hline 1 & Moderate & 0.03 & 0.16 & 0.19 & 1.48 & 1.86 & 44 \\
\hline 2 & High & 0.06 & 0.11 & 0.22 & 1.85 & 2.24 & 45 \\
\hline 3 & Low & 0.04 & 0.19 & 0.38 & 1.05 & 1.66 & 42 \\
\hline 5 & Low & 0.05 & 0.18 & 0.55 & 0.52 & 1.30 & 35 \\
\hline
\end{tabular}

pockets of smaller trees that regenerated in openings from previous fires are present, torching or transition to crown fire may occur (Kurbatsky 1970).

The equations we have developed for estimating separate crown fuel components from tree diameter and relating surface and ground fuel loadings to stand characteristics such as basal area and fuel depth, as well as average values on fuel loadings should be applicable to similar pine (P. sylvestris) forests in the central and southern taiga of Siberia, where specific field data are not available.

Feather moss surface fuels remain moist at much higher PV-1 than lichen surface fuels. Thus, lichen fuels are flammable under a much wider range of weather conditions. Lichen fuels also respond more rapidly to short-term changes in weather. An understanding of relationships between fuel moisture, weather patterns, and fire hazard indices such as PV-1 and FWI provides a foundation for modeling potential effects of seasonal weather patterns on fire behavior for Scots pine sites in central and southern Siberia.

Data on biomass, fuel characteristics and consumption like we presented here can be used to estimate the risk of fire ignition and spread, emissions, and fire intensity, and to support fire suppression efforts. Site- or forest typespecific data are required for understanding and modeling fire effects, emissions, and carbon stocks on individual sites and for improving existing global and regional models that require biomass or fuel characteristics. Similar data to those presented here are needed for other forest types in Siberia, including the extensive larch and spruce/fir forests. Ongoing studies (Chernykh and Furyaev 2011; Ivanova et al. 2011; Valendik et al. 2013) are helping to fill this gap. Postfire data from this and other studies (Buryak et al. 2011; Zhila et al. 2011; Kukavskaya et al. 2013a) are required to assess the long-term fire impacts on biomass fuel characteristics, carbon stocks, and vegetation dynamics.

Acknowledgements Cooperation and logistical support of the Russian Aerial Forest Protection Service (Avialesookhrana) and Russian Forest Service (Regional and Local Forestry Committees) is greatly appreciated. A special thanks to L. Bobkova, N. Koshurnikova, and E. Krasnoshchekova for their assistance in fuel sampling and to D. Randall for statistical analysis of tree data.

Open Access This article is distributed under the terms of the Creative Commons Attribution 4.0 International License (http://creativeco mmons.org/licenses/by/4.0/), which permits unrestricted use, distribution, and reproduction in any medium, provided you give appropriate credit to the original author(s) and the source, provide a link to the Creative Commons license, and indicate if changes were made.

\section{References}

Albini FA (1976) Estimating wildfire behavior and effects. USDA Forest Service, Intermountain Forest and Range Experiment Station General Technical Report INT-30, Ogden, UT, p 92

Alexander ME, Stocks BJ, Lawson BD (1991) Fire behavior in black spruce-lichen woodland: the Porter Lake project. Forestry Canada, Northern Forestry Centre Information Report NOR-X-310, Edmonton, AB, p 44

Amosov GA (1964) Some trends of surface forest fire development. In: Kurbatsky NP (ed) Forest fire occurrence. Nauka Publications, Moscow, pp 167-179 (in Russian)

Anderson HE (1982) Aids to determining fuel models for estimating fire behavior. General Technical Report INT-122. USDA FS, 
Intermountain Forest and Range Experiment Station, Ogden, UT, $\mathrm{p} 22$

Anuchin NP (1982) Forest inventory. Forest Industry, Moscow, p 552 (in Russian)

Atkin AS (1984) Phytomass and biological cycle in pine forests. IFandW SB AS USSR, Krasnoyarsk (in Russian)

Bannikova IA (1967) Influence of woody vegetation and small shrubs on subcanopy vegetation layer development. Nauka Publications, Moscow, p 104 (in Russian)

Baranov NM (1976) Forest fire danger in Baykal basin. In: Kurbatsky NP (ed) Forest fire protection in Baykal Basin. VN Sukachev Institute of Forest Publications, Krasnoyarsk, pp 12-28 (in Russian)

Bartalev SA, Stytsenko FV, Egorov VA, Loupian EA (2015) Satellitebased assessment of Russian forest fire mortality. Lesovedenie 2:83-94 (in Russian)

Burgan RE, Rothermel RC (1984) Behave: fire behavior prediction and fuel modeling system-fuel subsystem. U.S. Department of Agriculture, Forest Service. General Technical Report INT-167, Ogden, UT, p 126

Buryak LV, Luzganov AG, Matveev PM, Kalenskaya OP (2003) Impact of surface fires on the formation of light-coniferous forests of southern Central Siberia. Krasnoyarsk, SibSTU, p 206 (in Russian)

Buryak LV, Sukhinin AI, Kalenskaya OP, Ponomarev EI (2011) Effects of fires in ribbon-like pine forests of Southern Siberia. Contemp Problems Ecol 4:248-253

Byram GM (1959) Combustion of forest fuels. In: Davis KP (ed) Forest fire: control and use. McGraw-Hill, New York, pp 61-89

Canadian Forestry Service (1987) Tables for the Canadian Forest Fire Weather Index System, 4th ed. Canadian Forest Service Forest Technical Report No. 25, Ottawa, ON

Chernykh VA, Furyaev VV (2011) Forest fires in pine stands grown in belts of strips of Kulundinsk forest-steppe zone. Nauka, Novosibirsk, p 174 (in Russian)

Davis KP (1959) Forest fire: control and use. McGraw-Hill Book Co. Inc., New York, p 584

Deeming JE, Lancaster JW, Fosberg MA, Furman AW, Schroeder MJ (1972) The national fire-danger rating system. Research Paper RM-84, USDA Forest Service, Rocky Mountain Forest and Range Experiment Station, Fort Collins, CO, p 165

Elagin IN (1976) Seasonal development of pine forest. Nauka Publications, Novosibirsk, p 226 (in Russian)

FIRESCAN (1996) Fire in ecosystems of boreal Eurasia: the Bor forest island fire experiment Fire Research Campaign Asia-North. In: Levine JS (ed) Biomass burning and global change. MIT Press, Cambridge, pp 848-873

Forest Fund of Russia (1999) Data of State Forest Account, state by January 1, 1998 (1999) Reference book. All-Russian Research Center of Forest Resources, Moscow, p 649 (in Russian)

Groisman P, Shugart H, Kicklighter D, Henebry G, Tchebakova N, Maksyutov S, Monier E, Gutman G, Gulev S, Qi J, Prishchepov A, Kukavskaya E, Porfiriev B, Shiklomanov A, Loboda T, Shiklomanov A, Loboda T, Shiklomanov N, Nghiem S, Bergen K, Albrechtova J, Chen J, Shahgedanova M, Shvidenko A, Speranskaya N, Soja A, de Beurs K, Bulygina O, McCarty J, Zhuang Q, Zolina O (2017) Northern Eurasia Future Initiative (NEFI): facing the challenges and pathways of global change in the twentyfirst century. Prog Earth Planet Sci. https://doi.org/10.1186/s4064 5-017-0154-5

Ivanova GA (2005) Vegetation zone-specific characteristics of Scots pine forest fires in central Siberia. Dr Biol. Thesis. VN Sukachev Institute of Forest Publishing, Krasnoyarsk, p 40 (in Russian)

Ivanova GA, Perevoznikova VD (1996) Postfire formation of living ground cover in pine stands of the Middle Angara region. Sib Ecol $\mathrm{J}$ 1:109-116 (in Russian)
Ivanova GA, Kukavskaya EA, Conard SG, McRae DJ (2007) Fire influence on carbon emission in Scots pine forests of central Siberia. Sib Ecol J 6:885-895 (in Russian)

Ivanova GA, Conard SG, Kukavskaya EA, McRae DJ (2011) Fire impact on carbon storage in light conifer forests of the Lower Angara region, Siberia. Environ Res Lett 6:045203. https://doi. org/10.1088/1748-9326/6/4/045203

Johansson M-B (1994) Decomposition rates of Scots pine needle litter related to site properties, litter, quality, and climate. Can J For Res 24(9):1771-1781

Konev EV (1977) Physical fundamentals of vegetation material combustion. Nauka Publications, Novosibirsk, p 239 (in Russian)

Korovin GN (1996) Analysis of the distribution of forest fires in Russia. In: Goldammer JG, Furyaev VV (eds) Fire in ecosystems of boreal Eurasia. Kluwer Academic Publishers, Dordrecht, pp 112-128

Kovaleva NM, Ivanova GA, Kukavskaya EA (2011) Restoration of the ground cover after surface fires in pine forests of Middle taiga. Lesovedenie 5:30-35 (in Russian)

Kukavskaya EA, Buryak LV, Ivanova GA, Conard SG, Kalenskaya OP, Zhila SV, McRae DJ (2013a) Influence of logging on the effects of wildfire in Siberia. Environ Res Lett 8:045034. https:// doi.org/10.1088/1748-9326/8/4/045034

Kukavskaya EA, Soja AJ, Petkov AP, Ponomarev EI, Ivanova GA, Conard SG (2013b) Fire emissions estimates in Siberia: evaluation of uncertainties in area burned, land cover, and fuel consumption. Can J For Res 43(5):493-506. https://doi.org/10.1139/ cjfr-2012-0367

Kukavskaya EA, Ivanova GA, Conard SG, McRae DJ, Ivanov VA (2014) Biomass dynamics of central Siberian Scots pine forests following surface fires of varying severity. Int J Wildland Fire 23(6):872-886. https://doi.org/10.1071/wf13043

Kurbatsky NP (1962) Forest fire suppression procedures and tactics. Goslesbumizdat Publications, Moscow, p 154 (in Russian)

Kurbatsky NP (1970) Investigating forest fuel loading and properties. In: Kurbatsky NP (ed) Forest fire science problems. VN Sukachev Institute of Forest Publications, Krasnoyarsk, pp 5-58 (in Russian)

Kurbatsky NP, Ivanova GA (1987) Forest-steppe Scots pine stand fire danger and ways of its reduction. VN Sukachev Institute of Forest Publications, Krasnoyarsk, p 112 (in Russian)

Marchenko AI, Karlov EM (1961) To studying of vegetation biomass in northern taiga moss spruce forest. Bot J 46:1146-1152 (in Russian)

McRae DJ, Alexander ME, Stocks BJ (1979) Measurement and description of fuels and fire behavior on prescribed burns: a handbook. Environment Canada, Canadian Forest Service, Great Lakes Forestry Research Centre Information Report O-X-287. Sault Ste. Marie, ON, p 44

McRae DJ, Conard SG, Ivanova GA, Sukhinin AI, Baker SP, Samsonov YN, Blake TW, Ivanov VA, Churkina TV, Hao WM, Koutzenogij KP, Kovaleva N (2006) Variability of fire behavior, fire effects and emissions in Scotch Pine forests of central Siberia. Mitig Adapt Strat Glob Change 11:45-74

Melekhov IS (1947) Forest nature and forest fire. OGIZ Publications, Arkhangelsk, p 60 (in Russian)

Melekhov IS (1957) About forest floor accumulation by forest type. In: Kuibyshev VV (ed) Transactions of Forest Technology Institute. Forest Technology Institute Publications, Arkhangelsk, pp 124-137 (in Russian)

Morgan P, Hrady CC, Swetnam TW, Rollins MG, Long DG (2001) Mapping fire regimes across time and space: understanding coarse and fine-scale fire patterns. Int J Wildland Fire 10:329-342

Morisita M (1957) A new method for the estimation of density by spacing method applicable to nonrandomly distributed populations. Physiol Ecol 7:134-144 (in Japanese) (Available as Forest 
Service translation number 111 16, USDA Forest Service, Washington, D.C., USA.)

Ottmar RD, Sandberg DV, Riccardi CL, Prichard SJ (2007) An overview of the fuel characteristic classification system-quantifying, classifying, and creating fuelbeds for resource planning. Can J For Res 37:2383-2393

Pobedinsky AV (1979) Pine. Forest industry, Moscow, p 123 (in Russian)

Pozdnyakov LK, Protopopov VV, Gorbatenko VM (1969) Bioproductivity of forests in central Siberia and Yakutia. IFandW SB AS USSR, Krasnoyarsk, p 155 (in Russian)

Rodin LE, Bazelevich NI (1965) Organic matter dynamics and biological cycle of ash constituents and nitrogen in the main forest types of the world. Nauka Publications, Moscow, p 253 (in Russian)

Siberia Central (1964) Gerasimov IP (ed). Nauka Publications, Moscow, p 480 (in Russian)

Sofronov MA (1967) Forest fires in southern Siberian Mountains. Nauka Publications, Moscow, p 150 (in Russian)

Sofronov MA (1988) Fire-related characteristics of the upper Turukhan river basin vegetation. In: Glavatsky GO (ed) Forest fires and their suppression. VNIILM Publications, Moscow, pp 106-117 (in Russian)

Sofronov MA, Goldammer JG, Volokitina AV, Sofronova TM (2005) Wildland fire danger. Krasnoyarsk, VN Sukachev Institute of forest SB RAS, p 330 (in Russian)

Sofronova NI (1970) Diurnal changes of moisture content of some forest plants. In: Kurbatsky NP (ed) Forest fire science problems. VN Sukachev Institute of Forest Publications, Krasnoyarsk, pp 142-155 (in Russian)

Stocks BJ (1980) Black spruce crown fuel weights in northern Ontario. Can J For Res 10:498-501

Stocks BJ, Hartley GR (1995) Fire behavior in three jack pine fuel complexes. Natural Resources Canada, Canadian Forest Service, Great Lakes Forestry Centre, Sault Ste. Marie

Vagin AV, Murahtanov ES, Yshakov AI, Harin OA (1978) Forest inventory and forest management. Forest Industry Publications, Moscow, p 368 (in Russian)

Valendik EN (1990) Fighting with large forest fires. Nauka Publications, Novosibirsk, p 192 (in Russian)

Valendik EN, Gevel NF (1975) On consumption levels of some forest fuels. In: Kurbatsky NP, Konev EV (eds) Forest fire science problems. VN Sukachev Institute of Forest Publications, Krasnoyarsk, pp 127-137 (in Russian)

Valendik EN, Ivanova GA (1996) Extremal fire danger seasons in the boreal forests of the Central Siberia. Lesovedenie 4:12-19 (in Russian)

Valendik EN, Goldammer JG, YeK Kisilyakhov, Ivanova GA, Verkhovets SV, Bryukhanov AV, Kosov IV, Byambasuren O, the FIRESCAN Science Team (2013) Prescribed burning in Russia and neighbouring temperate-boreal Eurasia. Kessel Publishing House, Remagen, p 324

Van Wagner CE (1968) The line intersect method in forest fuel sampling. For Sci 1:20-26

Van Wagner CE (1987) Development and structure of the Canadian Forest Fire Weather Index System. Government of Canada, Canadian Forest Service, Technical Report 35, Petawawa, ON, p 37

Vasilevich VI (1969) Statistical methods in the geobotany. Nauka Publications, Leningrad, p 232 (in Russian)

Vedrova EF (2002) Decomposition rate of organic matter on the surface and in the soil. In: Pleshikov FI (ed) Forest ecosystems of the Yenisey Meridian. Publishing House of SB RAS, Novosibirsk, pp 231-240 (in Russian)

Vedrova EF, Spiridonova LV, Stakanov VD (2000) Carbon cycle in young stands of the main forest species of Siberia. Lesovedenie 3:40-48 (in Russian)

Venäläinen A, Korhonen N, Hyvärinen O, Koutsias N, Xystrakis F, Urbieta IR, Moreno JM (2014) Temporal variations and change in forest fire danger in Europe for 1960-2012. Nat Hazards Earth Syst Sci 14:1477-1490

Volokitina AV (1985) Layer-by-layer wetting and drying of moss/ lichen and litter ground covers in the forest. For Sci J 1:60-64 (in Russian)

Vonsky SM, Zdanko VA, Korbut VI, Semenov MM, Tetyusheva LV (1975) Natural forest fire danger rating: methodology guide. Leningrad Forestry Institute Publications, Leningrad, p 40 (in Russian)

Walker JD, Stocks BJ (1975) The fuel complex of mature and immature jack pine stands in Ontario. Department of the Environment, Canadian Forestry Service. Information Report O-X-229, Sault Ste Marie, Ontario, p 19

Zhila SV, Ivanova GA, Kukavskaya EA (2011) Transformation of ground cover biomass under the fire influence in light-coniferous forests of Lower Angara region. KrasSAU Herald 3:33-38 (in Russian)

Zhukov AB, Korotkov IA, Kutaphiev VP, Nazimova DI, Rechan SP, Savin EN, Cherebnikova YS (1969) Forests of Krasnoyarsk region. In: Zhukov AB (ed) USSR forests. Nauka Publications, Moscow, pp 248-320 (in Russian)

Zhukovskaya VI (1970) Hygroscopic forest fuel wetting and drying. In: Kurbatsky NP (ed) Forest fire science problems. Institute of Forest Publications, Krasnoyarsk, pp 105-141 (in Russian)

Publisher's Note Springer Nature remains neutral with regard to jurisdictional claims in published maps and institutional affiliations. 